Cornell Law Library

Scholarship@Cornell Law: A Digital Repository

Cornell Law Faculty Publications

Faculty Scholarship

$1-1-1980$

\title{
The Ordinary and the Extraordinary in Institutional Litigation
}

Theodore Eisenberg

Cornell Law School, ted-eisenberg@lawschool.cornell.edu

Stephen C. Yeazell

UCLA School of Law, yeazell@law.ucla.edu

Follow this and additional works at: http://scholarship.law.cornell.edu/facpub

Part of the Law and Society Commons, and the Litigation Commons

\section{Recommended Citation}

Eisenberg, Theodore and Yeazell, Stephen C., "The Ordinary and the Extraordinary in Institutional Litigation" (1980). Cornell Law Faculty Publications. Paper 698.

http://scholarship.law.cornell.edu/facpub/698

This Article is brought to you for free and open access by the Faculty Scholarship at Scholarship@Cornell Law: A Digital Repository. It has been accepted for inclusion in Cornell Law Faculty Publications by an authorized administrator of Scholarship@Cornell Law: A Digital Repository. For more information, please contact jmp8@cornell.edu. 


\title{
HARVARD LAW REVIEW
}

\section{THE ORDINARY AND THE EXTRAORDINARY IN INSTITUTIONAL LITIGATION}

\author{
Theodore Eisenberg* and Stephen C. Yeazell**
}

Institutional litigation, in which courts are requested to oversee the operation of large public institutions, has been frequently attacked as a departure from the traditional model of litigation. In this Article, Professors Eisenberg and Yeazell argue that the procedures and remedies employed in institutional litigation are not unprecedented but have analogues in older judicial traditions. Nor, they assert, do the doctrines of separation of powers and federalism present any obstacles to institutional litigation. They conclude that the novelty lies in the newly created substantive rights which courts are asked to enforce.

$\mathbf{I}_{\mathrm{p}}^{\mathrm{N}}$

recent years many writers have claimed to discover in prison, school, and mental hospital cases not just interesting lawsuits and new law but a whole new kind of litigation. Some commentators find novelty in the procedural and remedial characteristics of these cases, discerning the evolution of what was once a private, dualistic, and remedially limited system of dispute resolution into a public, multipolar, and flexible forum for the airing of social grievances. ${ }^{1}$ Others emphasize a different kind of novelty; one that lies less in procedure and remedy than in constitutional law and related prin-

* Acting Professor of Law, University of California, Los Angeles.

** Professor of Law, University of California, Los Angeles. The authors would like to thank Norman Abrams, Owen M. Fiss, Kenneth L. Karst, William M. McGovern, Jr., and David L. Shapiro for their thoughtful comments, and Jennifer Machlin and Mary Mitchell for their able research assistance. Generous financial support was provided by the Academic Senate of UCLA and the Dean's Fund of UCLA Law School.

'See, e.g., Chayes, The Role of the Judge in Public Law Litigation, 89 HaRv. L. REV. I28I (1976); Goldstein, $A$ Swann Song for Remedies: Equitable Relief in the Burger Court, I3 HARV. C.R.-C.L. L. REv. I (1978); Comment, Confronting the Conditions of Confinement: An Expanded Role for Courts in Prison Reform, I2 HARV. C.R.-C.L. L. REv. 367, 370 (1977). See also Cox, The New Dimensions of Constitutional Adjudication, 5I WASH. L. REV. 791, 821-29 (1976); Yeazell, Intervention and the Idea of Litigation: A Commentary on the Los Angeles School Case, 25 U.C.L.A. L. REV. 244, 246 (1977). 
ciples of federalism. ${ }^{2}$ For these observers the new litigation marks an important shift in the relation between courts and other branches of government, and in particular between federal courts and state government. Neither the proceduralists nor the constitutionalists are sure they like what they see; indeed, many chronicle the developments in institutional litigation with a distinctly lugubrious air. ${ }^{3}$ Whether or not they like such developments, however, the commentators agree that the cases present features breaking essentially new ground in procedure or constitutional law. We disagree.

In procedure, in remedy, and in constitutional law we believe there is more that links than divides the "new" litigation from other litigation, either past or present. We shall make this case for the essential continuity between the "old" and the "new" litigation in two stages. First, by examining the willingness of past and contemporary courts to supervise complex institutions, we hope to show that institutional litigation cannot be distinguished on purely procedural grounds. We examine some "extraordinary" characteristics of apparently ordinary litigation, arguing that much of what other commentators see as confined to institutional litigation is present, although in somewhat disguised forms, in all litigation. We shall then demonstrate that institutional litigation does not break dramatically new ground in constitutional doctrine or federalism; federalism may not compel the results in the institutional cases, but neither does it forbid them.

To say that the treatment of procedure, remedy, federalism, and constitutional law in institutional cases is unremark-

\footnotetext{
${ }^{2}$ See, e.g., D. Horowitz, The Courts and Social Policy (1977); Frug, The Judicial Power of the Purse, I26 U. PA. L. REv. 715 (1978); Mishkin, Federal Courts as State Reformers, 35 WASH. \& LEE L. REV. 949 (1978); Nagel, Separation of Powers and the Scope of Federal Equitable Remedies, 30 STAN. L. REv. 661, 718-23 (1978); Roberts, The Supreme Court Gambles in Allowing the Continuation of Federal Court Control Over a Local High School, 12 NEw ENG. L. Rev. 577 (1977). See also Cox, supra note I, at 82 I-29 (suggesting possible longrun costs of short term improvement in public institutions through judicial action).

${ }^{3}$ See, e.g., D. HoRowitz, supra note 2, at 293-98; Frug, supra note 2, at 733; Mishkin, supra note 2, at 950; Nagel, supra note 2, at 661-62. As do many of the lay observers who, in an unusually intense display of interest in non-Supreme Court cases, have commented on institutional litigation. Newspapers and magazines, unrestrained by the stodgy traditions of legal scholarship, are heralding or denouncing the new legal world in terms more colorful than are likely to survive law review editing. See Judging the Judges, TIME, Aug. 20, 1979, at 48-55; When Judges Govern, NEwsweek, Aug. 13, 1979, at 79. Aspects of the new litigation have been called "totalitarian" and "a mockery of justice." N.Y. Times, Dec. 10, 1975, at Ar, col. 2. Governor Wallace is reported as having claimed that "thugs and federal judges" are taking over the country. See The Real Governor, Time, Jan. 26, 1976, at $65-66$.
} 
able is not to say that these cases contain no novel elements. We think they do. But the novelty lies in substance and power, not in procedure and remedy. ${ }^{4}$ In institutional cases the courts have found in constitution and statute heretofore undreamed-of entitlements. ${ }^{5}$ These entitlements deserve far more discussion, for they represent fundamental choices respecting the distribution of social power, choices that should not be elided by concentrating on questions of procedure and federalism, or by sparring over the appropriate role of the courts. We shall have accomplished our purpose if we can refocus the debate on these questions of substance.

\section{The "New" Litigation: Some Cases and Their CRITICS}

Institutional litigation, while not precisely definable, typically requires the courts to scrutinize the operation of large public institutions. ${ }^{6}$ The suits are generally brought by persons

\footnotetext{
${ }^{4}$ Although our study will be from a perspective different if not broader than that underlying most commentary on institutional litigation, we shall not reexamine or comment on every detail of the cases. We shall not, for example, assess comprehensively the details of the particular remedies courts have ordered in institutional cases. The choice of a remedy - specifying guidelines, appointing masters, putting an institution into receivership, or ordering it closed - is in a larger sense a detail to be worked out according to one's judgment of its utility in any particular case. For discussion of these matters, see Goldstein, supra note I; Note, Implementation Problems in Institutional Reform Litigation, 9I HARV. L. REv. 428 (1977) [hereinafter cited as Implementation Problems]; Comment, Equitable Remedies: An Analysis of Judicial Utilization of Neoreceiverships to Implement Large Scale Institutional Change, I976 Wrs. L. REV. Ir6r; Note, The Wyatt Case: Implementation of a Judicial Decree Ordering Institutional Change, 84 YALE L.J. I338 (I975) [hereinafter cited as The Wyatt Case].

Similarly, we do not address in detail some questions about the doctrinal legitimacy of the injunctive remedies ordered in the new litigation. The controversial remedies have been equitable in nature and interesting questions may be asked about their propriety in light of traditional equity doctrine. For discussion of these matters, see O. Fiss, The CIVIL RIGHTS InJunction ( 1978 ), in which the traditionally disfavored status of injunctive relief is questioned. See also note 138 infra.

Nor do we wish to question some of Professor Chayes' insights into how the new litigation may differ from what has gone before. Chayes, supra note I. As Chayes shows, there are respects in which the judicial role, the litigant groups, and other aspects of institutional litigation may be viewed as novel: 16th century courts did not as a matter of course administer prisons.

${ }^{5}$ See Reich, The New Property, 73 YALE L.J. 733 (I964).

6 Though for our purposes it is not essential to define rigidly the outlines of institutional litigation, it may be useful at the outset to sketch very generally those characteristics which commentators see as institutional. They typically involve the courts in scrutinizing the operation of large public institutions. The suits are generally brought by persons subject to the control of those institutions, and the plaintiffs seek as relief some relatively elaborate rearrangement of the institution's mode of opera-
} 
subject to the control of the institutions who seek as relief some relatively elaborate rearrangement of the institution's mode of operation. It is important to recognize that institutional litigation does not include all litigation involving institutions. For example, cases that do no more than address the constitutionality of a statutory scheme governing institutions should not be characterized as institutional litigation. ${ }^{7}$ In those cases, the court's role is limited in the sense that there is no continuing judicial supervision of remedy. Perhaps the best way to identify the characteristics of the new institutional litigation is to briefly describe a pair of exemplary cases. The cases are exemplary both because they are complex and because they involve a particularly significant degree of judicial intrusion.

\section{A. The Cases}

Wyatt v. Stickney ${ }^{8}$ deserves paradigmatic status, for it has all the elements of a dramatic set piece: wretched mental patients, a steely-eyed judge of national prominence, ${ }^{9}$ a recalcitrant state bureaucracy, and a new constitutional right. If the development of the drama's plot is too slow for modern tastes, it is nevertheless instructive. The suit was precipitated by a reduction in the budget of Alabama's Bryce Hospital, a mental institution. ${ }^{10}$ A group of patients and discharged employees sued, alleging that conditions at the hospital - even

tion. For examples of the types of cases the writers classify as institutional, see, e.g., Chayes, supra note I, at I284; Frug, supra note 2, at 718-19 (prison conditions, mental hospitals, juvenile facilities); Comment, supra note 4 , at II83-88 (voting districts, school desegregation, prison conditions). See also note 7 infra.

${ }^{7}$ For example, in Goss v. Lopez, 419 U.S. 565 (1975), the Supreme Court ruled that suspended students were entitled at least to the rudiments of due process. It is not an institutional case as we and others use the term because the ruling, though it affected many schools, lacked the pervasive quality of judicial control manifested in typical institutional litigation. Indeed, cases can have even greater impact on institutions without becoming institutional cases. In Serrano v. Priest, 18 Cal. $3 \mathrm{~d} 728$, 557 P.2d 929, I35 Cal. Rptr. 345 (1976), cert. denied, 432 U.S. 907 (1977), the California Supreme Court held that a system of school finance based on property taxation violated principles of equal protection. The potential effect of the ruling is tremendous. At present, though, Serrano is simply a holding that a particular statutory scheme is unconstitutional. If the legislature refuses to remedy the defects identified by the court, and if the court then responds by devising and administering a tax system, Serrano will become an institutional case.

${ }^{8} 325$ F. Supp. $78 \mathrm{I}$ (M.D. Ala.), hearing on standards ordered, 334 F. Supp. $134 \mathrm{I}$ (M.D. Ala. 197 I), enforced, 344 F. Supp. 373 (M.D. Ala.); 344 F. Supp. 387 (M.D. Ala. 1972), aff'd sub nom. Wyatt v. Aderholt, 503 F.2d 1305 (5th Cir. 1974).

${ }^{9}$ District Judge Johnson, who presided over the Wyatt litigation, had already gained national attention for his desegregation decisions. See, e.g., R. KENNEDY, JUDGE FRANK M. JOHNSON, JR. I24 (1978).

${ }^{10} 325$ F. Supp. at 783 . 
before they were exacerbated by the budget cuts - were unconstitutional. ${ }^{11}$ Substantively, the suit turned on the recognition of the right of mental patients to some minimal level of medical treatment. That right, first recognized in Wyatt, ${ }^{12}$ has itself generated much commentary. ${ }^{13}$ Our focus, however, is on the implementation of the new right.

Although the court recognized a right to treatment, it initially declined to determine the standards "to be used in effectuating [that] right." 14 Instead it gave the defendant state officials three months to file a document describing their plans for treatment standards and another six months to implement them. ${ }^{15}$ The court said that if the defendants failed to meet these deadlines, it would appoint a pool of experts to study the Bryce programs. Presumably judicial intervention was limited at the outset on the ground that the Alabama officials had the expertise to effectuate reforms. ${ }^{16}$

Nine months later the court found that the defendants had failed to comply with their obligation to design and implement new treatment programs. ${ }^{17}$ It was still, however, reluctant to remove primary responsibility from the state officials. Rather than turning over the operation of the state's mental hospitals to a panel of masters, the court scheduled a hearing to allow the parties and amici to propose standards that would meet constitutional requirements. ${ }^{18}$ Eighteen months after the suit was filed, on the basis of this hearing, the court issued an interim emergency order relating to conditions at one of the institutions. ${ }^{19} \mathrm{~A}$ month later it issued a more extensive order detailing minimum treatment and care standards. ${ }^{20}$ This later order contained the elaborate detail that is one hallmark of the "new" institutional litigation: it specified such aspects of insti-

11 The Wyatt Case, supra note 4 .

12325 F. Supp. at 785 .

${ }^{13}$ The Wyatt Case, supra note 4, at 1339 n.5 (collecting authorities).

14325 F. Supp. at 785 .

15 Id. at $785-86$.

16 The court also tried to improve the general quality of mental health administration in Alabama. While the case was pending there was a reorganization of the Alabama Department of Health, the agency with jurisdiction over state mental health facilities. The Department was being reorganized to deliver more efficient and effective care to patients within the system by adopting a unit-team approach to mental health delivery services. Id. at 785 . The court stated that one reason it reserved judgment on plaintiffs' motion was to "allow the defendants a reasonable time to implement fully the unit-team approach and to measure the effectiveness of the [approach] at the Bryce facility." Id.

${ }^{17} 334$ F. Supp. I34I (M.D. Ala. I97I).

18 Id. at $\mathrm{I} 344$.

${ }^{19}$ See The Wyatt Case, supra note 4, at $\mathrm{r} 349-50$ \& n.57.

${ }^{20} 344$ F. Supp. 373, 387 (M.D. Ala. 1972). 
tutional life as clothing allotments, linen, telephone and mail privileges, food expenditures for residents, and staff qualifications. ${ }^{21}$ Even this detailed system of supervision, however, produced no magical solutions, and the Wyatt litigation required many more decisions by the court. ${ }^{22}$

Prisons as well as hospitals have given rise to much of the new litigation. Holt $v$. Sarver, ${ }^{23}$ a relatively early prison case that spans many years, is representative. In the first phase of litigation, Holt I, inmates challenged conditions at the Cummins Farm Unit of the Arkansas State Penitentiary alleging cruel and unusual punishment in violation of the eighth amendment. ${ }^{24}$ The court found that the prison authorities had failed to insure minimal physical safety for the inmates of Cummins. $^{25}$ No detailed institutional changes were ordered, however. Eight months later, in Holt II, the court focused on the trusty system under which preferred inmates served as guards. ${ }^{26}$ The court held that conditions at Cummins and at Tucker Reformatory, another institution whose inmates had joined the suit, were still unconstitutional. ${ }^{27}$

${ }^{21}$ Id. at $379-86,395-406$.

The detailed final decree in Wyatt did not place the institutions in receivership or order the appointment of a master. Instead, the court appointed a seven-member Human Rights Committee to oversee each institution's compliance with constitutional standards and ordered that an experienced administrator be hired to implement the necessary programs. Id. at $378,392,394$. The court also refused to order specific money-raising measures to implement its standards, noting that judicial deference to the legislative funding prerogative was desirable. It stated, however, that a lack of funds would not excuse a failure to comply. Id. at 394 .

22 Many of the subsequent decisions concerned the functioning of the Partlow Human Rights Committee. See The Wyatt Case, supra note 4, at 1354-64, 137376. The Fifth Circuit later affirmed the substance of what Judge Johnson had ordered. Wyatt v. Aderholt, 503 F.2d 1305 (5th Cir. 1974).

${ }^{23} 300$ F. Supp. 825 (E.D. Ark. 1969); 309 F. Supp. 362 (E.D. Ark. 1970), aff'd, 442 F.2d 304 (8th Cir. $197 \mathrm{I}$ ). For earlier litigation involving conditions at the same penal institutions, see Courtney v. Bishop, 409 F.2d II85 (8th Cir. 1969), cert. denied, 396 U.S. 915 (1970); Jackson v. Bishop, 404 F.2d 57 I (8th Cir. I968), vacating 268 F. Supp. 804 (E.D. Ark. 1967); Talley v. Stephens, 247 F. Supp. 683 (E.D. Ark. I965).

24300 F. Supp. 825,826 (E.D. Ark. 1969).

${ }^{25} \mathrm{Id}$. at 830-33.

${ }^{26} 309$ F. Supp. 362 (E.D. Ark. 1970).

${ }^{27} \mathrm{Id}$. at 38r. Isolation cells remained overcrowded and filthy. Id. at 378. There was no rehabilitation program at Cummins. Id. at 378-79. Surroundings were generally "degrading and disgusting." Id. at 38r. Medical and dental facilities left "much to be desired." Id. at 380 . Sanitary conditions in the kitchen were deplorable. Id. Inmates were given insufficient socks and underclothing, no towels, and were required to sleep on filthy bedding. Id. Racial segregation was practiced at Cummins. Id. at $38 \mathrm{I}-82$. 
The court in Holt II expressed respect for Arkansas' prerogatives and, like the court in Wyatt, was reluctant to establish a comprehensive remedial program. ${ }^{28}$ It simply ordered Arkansas officials "to make a prompt and reasonable start toward eliminating" the unconstitutional conditions in Arkansas' prisons. ${ }^{29}$ The officials were also required to report within six weeks on what had been done to remedy conditions and what plans had been made for future compliance. ${ }^{30}$ Although the court recognized the difficulty of providing funds for reforms and expressed hope that pending legislation would help alleviate that problem, it nevertheless clearly stated that lack of funds would not excuse continued operation of inhuman prisons and threatened to close those prisons if necessary. ${ }^{31}$

Three years later, in spite of further proceedings ${ }^{32}$ and some improvement in conditions, ${ }^{33}$ the Eighth Circuit held that the correctional authorities had not yet provided a constitutional environment within the prisons. ${ }^{34}$ The conditions found to be unconstitutional on appeal could not have come as complete surprises to prison authorities. Most of the problems mentioned by the court of appeals had been carefully considered by the district court. In some instances the district

${ }^{28} I d$. at 382 (quoting Holt $I, 300 \mathrm{~F}$. Supp. at 833 ).

${ }^{29} \mathrm{Id}$. at 383 .

${ }^{30} \mathrm{Id}$. at 385 .

${ }^{31} I d$. at 383,385 .

${ }^{32}$ Holt II was decided in February 1970. Progress reports were filed with the court in 1970 and 1971 and at the end of 197 I the court supplemented its decree. See Holt v. Hutto (Holt III), 363 F. Supp. I94 (E.D. Ark. I973), aff'd in part, rev'd in part sub nom. Finney v. Arkansas Bd. of Correction, 505 F.2d x94 (8th Cir. 1974). Prisoner complaints continued and in November and December of 1972 and January of 1973 the court conducted hearings on the new complaints, which it had ordered consolidated with the earlier cases. In Holt III, supra, the district court concluded that conditions were substantially better, see note 33 infra, that there were continuing problems, but that they did not rise to the level of unconstitutionality. Id. at 200-or.

${ }^{33}$ The district court in Holt III noted that because of changing attitudes and efforts on the parts of legislative, executive, and administrative officials in Arkansas, the prison system had improved. Widespread unconstitutional conditions and practices were no longer officially sanctioned by the prison system. The infamous trusty system had been all but disbanded, the quality and security of barracks life, though still not ideal, had been improved, and a new maximum security unit had been built at Cummins to house "the most dangerous and unstable inmates." The system had acquired law libraries for inmates at both institutions and the Department employed a lawyer to serve as legal advisor to inmates of Cummins and Tucker. For the first time the Department had retained a full-time physician to give medical assistance to the more than 1400 inmates incarcerated at the two institutions. $363 \mathrm{~F}$. Supp. at I98-200.

34 Finney v. Arkansas Bd. of Correction, 505 F. 2d 194, 200 (8th Cir. 1974). 
court had expressly disapproved of one or more aspects of the system but had refused to find the particular practice constitutionally infirm or had relied on the good faith and diligence of state officials to remedy the problem. In any event, although some progress had been made, grave constitutional weaknesses remained more than five years after the initial Holt decision. ${ }^{35}$ On remand the district court again reviewed prison conditions in detail, ordered further relief, and awarded substantial attorney's fees. ${ }^{36}$

\section{B. The Critics}

Most of the commentary on Holt, Wyatt, and similar cases suggests that something drastically new is afoot. ${ }^{37}$ But a wide variety of views have been expressed about the exact nature of the break between the modern institutional cases and the forms of litigation in some past golden age. To some, the institutional cases are merely a manifestation of "judicial activism." 38 This label may represent disagreement with results or it may be intended to suggest that courts are acting in areas more properly within the executive and legislative spheres of responsibility. Other critics more precisely evoke two constitutional themes to explain how judicial behavior in institutional litigation cases violates traditional separation of powers principles. One line of criticism argues that the administration of institutions is an executive function. ${ }^{39}$ Other writers seem more troubled by the fear that courts might actually enforce their decrees by ordering the expenditure of public funds. ${ }^{40}$

The second line of criticism argues that institutional litigation violates principles of federalism. While federalism may no longer effectively limit congressional power over state affairs ${ }^{41}$ the doctrine flourishes in federal courthouses. One can

${ }^{35} I d$.

${ }^{36}$ Finney v. Hutto, 4 Io F. Supp. 25I (E.D. Ark. 1976), aff'd, 548 F.2d 740 (8th Cir. 1977), aff'd, 437 U.S. 678 (1978). For still later proceedings related to Holt, see Finney v. Mabry, 455 F. Supp. 756 (E.D. Ark.); 458 F. Supp. 720 (E.D. Ark. 1978).

${ }^{37}$ See, e.g., Frug, supra note 2, at 718-30; Nagel, supra note 2, at 661-62, 708. See generally Chayes, supra note I, at I288-304.

${ }^{38}$ See, e.g., Frug, supra note 2, at 716.

${ }^{39}$ See, e.g., Nagel, supra note 2, at 662; cf. Mishkin, supra note 2, at 958 (institutional cases bypass majoritarian political controls).

${ }^{40}$ See, e.g., Frug, supra note 2, at 733; Mishkin, supra note 2, at 959, 965, 969.

${ }^{41}$ See, e.g., Milliken v. Bradley, 433 U.S. 267 (1977); Fitzpatrick v. Bitzer, 427 U.S. 445 (1976); Katzenbach v. McClung, 379 U.S. 294 (1964); Wickard v. Filburn, 3 I7 U.S. III (1942). But see National League of Cities v. Usery, 426 U.S. 833 (1976); Oregon v. Mitchell, 400 U.S. II2 (1970). 
employ several recent cases to construct a plausible argument that litigation involving state institutions transgresses some limit on the legitimate authority of the federal judiciary. ${ }^{42}$ In skeletal form the argument is simple. The federal government generally defers to state authority in areas of traditional state functions. These functions include the operation of prisons, hospitals and schools. Therefore, the federal judiciary should not assume administrative responsibilities for those state institutions. ${ }^{43}$

Commentary focusing on the procedural novelty of institutional litigation asserts that the remedial phases of these cases are extraordinary. ${ }^{44}$ Many critics believe that the detailed and prospective nature of the decrees separates institutional litigation from traditional adjudication; they describe the remedial phases of cases such as Wyatt and Holt as a "new species" 45 of litigation, representing a "new remedial activism" 46 by judges and involving "innovative and expansive remedies." 47

A related strand of commentary on the remedial phase of institutional cases notes the new supervisory responsibility taken on by courts. The openended and detailed decrees in institutional cases are said to involve courts in performing administrative and supervisory tasks with which they have little familiarity and for which they have few qualifications. The supervisory burdens are sometimes seen as a responsibility of other branches of government ${ }^{48}$ and sometimes merely said to be new for courts, without reference to other branches of government. ${ }^{49}$ Judges are alleged to have stepped into unaccustomed roles as "they become responsible for implementing broad reforms in complex administrative systems." 50

42 See National League of Cities v. Usery, 426 U.S. 833 (r976); Rizzo v. Goode, 423 U.S. 362 (I976); O'Shea v. Littleton, 4I4 U.S. 488 (I974); Younger v. Harris, 40 I U.S. 37 (197I).

${ }^{43}$ See Frug, supra note 2, at 743-49; Mishkin, supra note 2, at 965, 967-7I.

${ }^{44}$ E.g., Chayes, supra note $\mathrm{I}$, at 1289 ("[There is] a new model of judicial action and the judicial role, both of which depart sharply from received conceptions.").

45 Implementation Problems, supra note 4 , at 428.

${ }^{46}$ Robbins \& Buser, Punitive Conditions of Prison Confinement: An Analysis of Pugh v. Locke and Federal Court Supervision of State Penal Administration Under the Eighth Amendment, 29 STAN. L. REV. 893, 894 (I977).

47 Nagel, supra note 2, at 66r. See also Cox, supra note I, at 8I9 (referring to "entirely novel forms of judicial action").

${ }^{48}$ E.g., D. Horowitz, supra note 2, at 293-98; Frug, supra note 2, at 789.

${ }^{49}$ See Implementation Problems, supra note 4 , at $428,46 \mathrm{I}-63$.

${ }^{50} \mathrm{Id}$. at 428 . 


\section{IntRansigence and Supervision In the Old AND New litigation: The Historical Continuity}

In making such assertions, critics implicitly assume that in traditional litigation the courts employ less "extraordinary" methods for resolving disputes. We think that this vision of the traditional legal system is too narrow. In fact, one finds "extraordinary" elements in the old litigation and discovers that the new litigation presents relatively little that is genuinely novel.

\section{A. The "Normal" Lawesuit}

According to the traditional model of litigation, all of the complex, uncertain, and messy problems are addressed before a decision on the merits is reached. The difficult task in a "normal" lawsuit is to decide what happened and to determine which legal doctrines are applicable. ${ }^{51}$ Once that is done, the result flows smoothly. If the plaintiff has failed to convince the court of the merits of his claim, he will slink off to a corner, and perhaps litigate another day; if the defendant is judged liable he will pay, assuming he has money. ${ }^{52}$ The court's involvement in the affairs of the adversaries is terminated when a judgment issues; the dramatic finality of its decree prevents the dispute from boiling over again. ${ }^{53}$

This picture of litigation and its results is familiar and in some respects appealing. It enhances the prestige of the courts; in "normal" litigation, courts are spared the indignity of running a hospital, of deciding whether a business has hired enough blacks, or of determining how much toilet paper a prisoner assigned to solitary confinement must be issued. The traditional picture also enhances the political legitimacy of the courts. Always nervous about the power exercised by unelected bodies, ${ }^{54}$ we are comfortable only when we believe that the discretion of the courts is narrowly confined. ${ }^{55}$

${ }^{51}$ See, e.g., D. HoRowit, supra note 2, at 45 ("The judicial fact-finding process carries forward this abstraction of the case from its more general social context.").

52 See, e.g., Chayes, supra note $\mathrm{I}$, at 1283 :

The lawsuit is a self-contained episode. The impact of the judgment is confined to the parties. If plaintiff prevails there is a simple compensatory transfer, usually of money, but occasionally the return of a thing or the performance of a definite act. If defendant prevails, a loss lies where it has fallen. In either case, entry of judgment ends the court's involvement.

53 Id.

${ }^{54}$ See, e.g., Frug, supra note 2, at 734-35 (expressing traditional concern about judicial interference with democratic decisionmaking); Mishkin, supra note 2, at 958 .

${ }^{55}$ See, e.g., Chayes, supra note $\mathrm{I}$, at $\mathrm{I} 288$. 
What such a picture ignores, of course, is reality. It disregards the very considerable amount of energy spent in attempts to force intransigent parties to comply with decrees. While none of us really believes that all litigants willingly comply with decrees, we often talk and think about the propriety of judicial activism as if they did. We overlook the many detailed, coercive, and intrusive techniques that the legal system employs to deal with intransigent litigants before, during, and after traditional litigation.

Indeed, it is precisely because such devices are so common in traditional litigation that they have become institutionalized, routine, and therefore invisible. We hope to render these aspects of the old litigation more visible. Much of what seems unusual about the new litigation is in fact merely the use of familiar procedures in novel substantive contexts.

\section{B. Intransigence and Judicial Power: Ordinary Litigation as an Extraordinary Event}

Courts exist to resolve the disputes of parties who have been unable to settle their differences by some other means parties who are particularly intransigent. To the experienced attorney, the existence of judicial techniques to control this intransigence seems inevitable. Ordinary people, however, typically find their presence before a court to be a traumatic, "extraordinary" event. ${ }^{56}$ This lay reaction reveals something about the judicial process that those trained in the law often fail to recognize.

Litigation itself is abnormal, an extraordinary event in which courts tinker with people's lives and compel them to do all sorts of distasteful things over lengthy periods of time. The extraordinary nature of litigation is attested to both by its infrequency relative to all other forms of dispute resolution and by judicial willingness to interfere only if necessary. ${ }^{57}$

\footnotetext{
56 If a sufficiently broad perspective is adopted, the very existence of a legal system can be seen as in some sense extraordinary. See R. UNGER, LAW IN MODERN SocIETY 47-I33 (I976).

57 In an elaborately designed survey of the use of lawyers by the American public, the American Bar Foundation discovered that in a sample designed to replicate a random cross section of the population, one-third had never consulted a lawyer about any matter at any time in their lives, and of the remaining portion (those who had at any time seen a lawyer) approximately one-half had seen the lawyer about a matter involving real property or estate planning. If one realizes that in many states lawyers handle routine transfers of real estate, it is evident that seeing a lawyer about any dispute, much less one that leads to litigation, is a rarity in the average life in spite of our collective moaning about the society's litigiousness. B. CURRAN, THE LEGAL
} 
Litigation involves forms of coercion that, if they occurred in the context of framing a remedy, would be seen as extraordinary and quite possibly "unjudicial." The procedures of compelled testimony and cross examination which are routinely used by courts require people to appear, under threat of punishment, in uncomfortable rooms and wait for long periods of time so that they can engage in discourse with complete strangers - at least one of whom may be quite hostile to them. ${ }^{58}$ Moreover, adversaries in a "typical" litigation are frequently forced to engage in discussion under the leadership of a facilitator; this practice is commonly known as oral testimony or deposition. ${ }^{59}$ Modern procedural rules go a good deal farther: parties to lawsuits may be required to permit their antagonists to walk around on their land poking sticks in the ground and making various tests; ${ }^{60}$ they may also be compelled to submit to physical and psychiatric examinations ${ }^{61}$ and to supply written answers to numerous and often harassing questions put by adversaries trying to catch them in an inconsistency. ${ }^{62}$

In short, the most fundamental aspect of modern trials the process by which factual contentions are narrowed, developed, and tried - requires the courts to coerce a good deal of human interaction, interaction that is remarkably like that compelled in many of the decrees issuing as a result of the "new" litigation. Thus the simplest cases, even those that end with decrees instantly obeyed by all concerned, involve much that is "extraordinary" in the sense in which that term is used by the new commentators. But in fact, even more specialized procedures are employed to deal with those who present various specialized forms of intransigence.

1. Intransigence and Special Circumstances: Default Judgments and Long-Arm Jurisdiction. - At the outset of a law-

NeEdS of THE PUBLIC I85, 203 (2d ed. 1977). See also Macaulay, Non-Contractual Relations in Business, 28 AM. Soc. REV. 55 (1966).

Courts generally do not become involved in forcing people to go to trial without some sign that this sort of governmental intervention will be necessary. The existence

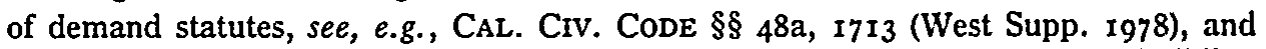
administrative exhaustion requirements, see, e.g., Myers v. Bethlehem Shipbuilding Corp., 303 U.S. 4I (1938); Government Organization and Employees Act of 1966, $\S 704,5$ U.S.C. $\$ 704$ (1976), indicate that society wants litigation to be viewed as extraordinary.

${ }^{58}$ See, e.g., Fed. R. Civ. P. 54; CAL. Civ. Proc. Code $§ 2064$ (West r955).

59 See FED. R. Civ. P. 30.

${ }^{60}$ See Fed. R. Civ. P. 34; Cal. Civ. Proc. Code $\$ 203$ I (West Supp. 1978).

${ }^{61}$ See, e.g., FEd. R. Civ. P. 35; CAL. Civ. Proc. CODE $\$ 2032$ (West Supp. 1979). See also Schlagenhauf v. Holder, 379 U.S. I04 (1964); Edwards v. Superior Court, r6 Cal. 3d 905, 549 P.2d 846, I30 Cal. Rptr. I4 (1976).

${ }^{62}$ See Fed. R. Civ. P. 33; Cal. Crv. Proc. Code $§ 2030$ (West Supp. 1978). 
suit, courts exercise their coercive powers when dealing with a party who refuses to engage in the coerced dialogue and indignity characteristic of judicial dispute resolution. An uncooperative defendant may decline to deal with the court at all by refusing to acknowledge its jurisdiction. As every firstyear student of procedure knows, the courts have an entirely familiar "extraordinary" means of dealing with this situation: they subject the defendant to a default judgment, ${ }^{63}$ which results in the potential seizure and sale of his property without a hearing - the ultimate in strong-arm tactics. ${ }^{64}$

While defendants can reopen default judgments without tremendous difficulty, ${ }^{65}$ we must not permit the existence of such second-chance procedures to blind us to the draconian nature of the default judgment. It is, after all, a remedy in which the court authorizes an arm of the government to first locate, seize, and sell the assets of defendant, and then to subtract from them certain administrative fees, turning over the amount of the judgment to the plaintiff and the remainder, if any, to the defendant. ${ }^{66}$ It is a proceeding in which the state takes over an asset and transforms it into another form of property, all for the purpose of assuring compliance with a court order. Significantly, this procedure occurs prior to any findings of fact by the court that the defendant is liable.

The exercise of long-arm jurisdiction magnifies the drastic nature of the default judgment. When such jurisdiction is invoked, the defendant subjected to the court's power may be a continent or an ocean distant from the scene. ${ }^{67}$ In our efforts to untangle the baroque complexities of personal jurisdiction clarified only slightly by the Supreme Court's recent efforts to iron out the doctrine's most pronounced wrinkles 68 - we tend to forget the degree to which it permits state court intrusion into the affairs of nonresidents.

The doctrine controlling long-arm jurisdiction is itself a response to circumstances in which "ordinary" procedures seem unsatisfactory. It is a commonplace to point out that the development of jurisdiction over defendants not present in the

${ }^{63}$ See, e.g., Fed. R. Civ. P. 55; Cal. Civ. Proc. Code $\$ \S 585,586$ (West I976).

${ }^{64}$ Cf. FED. R. Crv. P. 54(c) ("A judgment by default shall not be different in kind from or exceed in amount that prayed for in the demand for judgment.").

${ }^{65}$ See, e.g., FeD. R. Crv. P. 55(c); Cal. Crv. Proc. Code $§ 585.5$ (West r978).

${ }^{66}$ See, e.g., Fed. R. Civ. P. 69; CAL. Civ. Proc. CoDe $\$ 684.2$ (West Supp. 1978); N.Y. Crv. PRAC. LAW § 5236 (McKinney I978).

${ }^{67}$ See, e.g., Fed. R. Civ. P. 4(e); Cal. Civ. Proc. Code § 4IO. IO (West 1973); Buckeye Boiler Co. v. Superior Court, 7 I Cal. 2d 893, 458 P.2d 57, 80 Cal. Rptr. II3 (I969); Bryant v. Finnish Nat'l Airline, I5 N.Y.2d 426, 208 N.E.2d 439, 260 N.Y.S.2d 625 (I965).

${ }^{68}$ See Shaffer v. Heitner, 433 U.S. I86 (r977). 
forum state was the twentieth century's response to the mobility of an industrial society. ${ }^{69}$ Lost behind this commonplace is the recognition that the procedure was specially tailored to a situation that had become more common with changing social circumstances. Long-arm jurisdiction grew out of the desire to afford speedier and cheaper redress to the citizen of state $A$ engaged in a dispute with the defendant of state $B$.

Long-arm jurisdiction is in no sense a necessity, since the plaintiffs in question almost always have available an alternative remedy - suit in the defendant's home state, where the courts are bound to render justice to the nonresident on the same terms as they do to their own citizens. ${ }^{70}$ Thus long-arm jurisdiction is at least in part an accommodation to the home state plaintiff. The creation of that specialized procedure places the defendant at a tactical disadvantage. In addition to the burdens of litigation already described, he must now choose between default and the increased expenses of litigating in a distant forum.

Recognizing the nonessential characteristic of long-arm jurisdiction aids analysis of the arguments made about the breadth and depth of decrees in public litigation. These decrees are not always strictly necessary; other means, less advantageous to the plaintiff, but more fair to the defendant, may be available. For example, a decree simply requiring a school board to refrain from racially motivated school location might, in the course of a generation, reduce racial segregation in the schools while saving money and preserving the school board's traditional, politically accountable control over the schools. More drastic decrees, ordering substantial expenditure of funds for a more rapid elimination of the effects of segregation, provide advantages in many respects analogous to the advantages long-arm jurisdiction gives to the plaintiff who could sue in another state. Both procedures represent judgments about the desirability of assistance for a class of plaintiffs in special circumstances. People may, of course, differ about the wisdom of such "special" judicial help; what is not open, we contend, is the assertion that such help is inherently "unjudicial."

2. Execution Before Trial: Prejudgment Remedies. - For many centuries courts have employed another specialized form of judicial coercion as a standard litigative weapon - attach-

${ }^{69}$ See, e.g., P. Carrington \& B. Babcock, Civil Procedure 862-63, 894 (2d ed. 1977); F. James \& G. Hazard, Civil Procedure 630-34 (2d ed. 1977).

${ }^{70}$ U.S. ConsT. art. IV, \& 2; see Currie \& Schreter, Unconstitutional Discrimination in the Conflict of Laws: Privileges and Immunities, 69 YALE L.J. 1323, 1384 (I960). 
ment. Under this procedure, property of the defendant is seized before trial and placed in the hands of a third party. This property is then used to satisfy any resulting judgment. ${ }^{71}$ The Supreme Court has addressed constitutional questions regarding such power and, in most situations, now requires some preliminary determination of the necessity for seizure and a showing of the probability that the plaintiff will ultimately prevail on the merits. ${ }^{72}$ For our purposes the important thing is the continued and unquestioned use of these procedures for a number of centuries. ${ }^{73}$ They represent, after all, a quite dramatic form of judicial power: the court's officer, upon the barest of assertions by the plaintiff, takes control of some property of the defendant, removes it from his possession, preserves it safe from harm in some place inaccessible to the defendant, and, if the defendant finally wins the lawsuit, returns it to him without suggesting that anything out of the ordinary has happened. Use of this device places enormous bargaining power in the hands of the plaintiff, a far greater power than is usual in institutional litigation.

Garnishment is in many respects an even more intrusive remedy than attachment. It not only disadvantages the defendant before the court has determined that any disadvantage is warranted but also requires a third party - the garnishee, who no one asserts is guilty of any wrong - to assist plaintiff, on pain of liability, in a fight with which he has nothing to do. In this respect a bank or an employer, to choose two common garnishees, stands in a position similar to that of schoolchildren bused to compensate for a wrong the governing authorities have committed. Of course the degree of intrusion into schoolchildren's lives is more severe and permanent than the intrusion into the bank's operations, but interference exists, nevertheless. Garnishment forces a third party to become a guardian of the plaintiff's interests; the garnishee is compelled to assume the role of a temporary trustee.

3. "Ordinary" Intransigence: Levy and Execution. - Perhaps because creditors' remedies are generally taught in a separate course taken predominantly by students of a certain

${ }^{71}$ See R. Millar, Civil Procedure of the Trial Court in Historical PERSPECTIVE 485-5I6 (1952) (history of the use of these specialized procedures).

${ }^{72}$ See North Ga. Finishing, Inc. v. Di-Chem, Inc., 4I9 U.S. 60I (I975) (striking down Georgia's garnishment statute); Mitchell v. W.T. Grant Co., 4I6 U.S. 600 (1974) (narrowly upholding Louisiana's sequestration procedure in a case involving a vendor's lien); Fuentes v. Shevin, 407 U.S. 67 (1972) (holding Florida and Pennsylvania replevin statutes unconstitutional); Sniadach v. Family Fin. Corp., 395 U.S. 337 (1969) (holding Wisconsin's wage garnishment statute unconstitutional).

73 See, e.g., Mass. ANN. Laws ch. 246 (Michie/Law. Co-op Supp. 1978); N.Y. Civ. Prac. LAW $\S \S 6201,62$ II (McKinney Supp. I978). 
bent of mind, it is easy to lose sight of a quite ordinary procedure that has about it many of the marks of the "extraordinary" remedies that commentators decry. We have in mind the congeries of devices that surround the translation of a judgment into satisfaction of the successful plaintiff.

It frequently happens that the losing defendant is solvent but chooses not to satisfy the judgment. ${ }^{74}$ When this happens, courts employ a procedure for transforming an asset owned by the intransigent defendant into one more useful to the judgment creditor: the sheriff attaches the asset, providing the debtor with fairly strong evidence that the creditor means business. ${ }^{75}$ If that fails to produce payment, the sheriff sells the asset and delivers to the creditor a portion of the proceeds equal to the amount of the judgment. ${ }^{76}$ The procedure, so routine and so specialized that we often fail to think of it as part of litigation proper, is neither inevitable nor unintrusive. In effect, officers of the state are empowered to seize the property, and to act as dual fiduciaries for the creditor and debtor, holding the property as a "trust" that can be used to render payment to the creditor in a convenient form in relatively quick order.

Moreover, courts have developed procedures to deal with debtors whose assets do not readily present themselves for tender treatment at the sheriff's hands. Under the law of many states, after the sheriff has indicated that he is unable to discover attachable property, the debtor can be hailed into court once more and subjected to examination on the existence and value of any property he may have. ${ }^{77}$ One can imagine less intrusive judicial forms of execution, procedures that delayed payment to the creditor until the debtor converted his asset to cash. $^{78}$ Adopting such a practice would resemble a decision to limit remedial decrees in racial discrimination cases to alteration of the future conditions of employment or edu-

\footnotetext{
${ }^{74}$ For example, a solvent defendant would be reluctant to satisfy the judgment if liquidation of his assets would entail a significant loss.

${ }^{75}$ See, e.g., Cal. Civ. Proc. Code §§ 682(a), 684 (West Supp. 1978).

${ }^{76} \mathrm{See}$, e.g., id. $\S 684$. The procedures following a judgment on the merits are similar to those employed in default judgments. See note 64 supra.

${ }^{77}$ See, e.g., CAL. Crv. Proc. Code $\S 7$ I4 (West Supp. 1978).

${ }^{78}$ Such a system lies at the heart of our system of income taxation in which, to simplify administration and to ease the taxpayers' cries of pain, we consider taxing gains only at the point they are realized. See Eisner v. Macomber, 252 U.S. 189 (1920).

One of the earliest statutes concerned with debt collection contained a similar delaying provision; the Statute of Merchant gave the debtor three months to liquidate his assets before they passed to his creditor. The Statute of Merchant, 1285, 13 Edw. I, c. I.
} 
cation; waiting until some future opportunity for action presents itself is far less intrusive than taking immediate action to redress past wrongs.

The view that the traditional lawsuit ends almost amicably, at a stage well before the administration of the remedy, is artificial. In this "old" litigation, as in the public litigation that has engendered so much outcry, administering remedies often creates resistance, and the courts must expend a great deal of energy and devise ingenious procedures to overcome such resistance. In order, therefore, properly to compare the "old" and "new" litigation, one would have to juxtapose the doubtless edifying but unfortunately rare examples of the judgment debtor who instantly pays and the school board that immediately embarks on a wide-ranging program of integration and compensatory education once it has been shown the constitutional error of its ways. Or, more realistically, one would have to place beside Wyatt, in which a federal judge oversaw administration of Alabama mental hospitals, ${ }^{79}$ the numerous cases in which courts have ordered prejudgment attachment, entered default judgments, resorted to long-arm jurisdiction, or attempted to locate hidden assets. The differences that would emerge would not be as considerable as many commentators would have us believe.

\section{Complexity as a Cause of Extraordinariness: Judicial Supervision of Complex Enterprises}

Many of the remaining differences between "old" and "new" litigation quickly pale once it is recognized that old litigation frequently involves the elaborate decrees requiring continuous supervision that is quite common in institutional cases. In several substantively distinct areas, a judgment has been made that continuing supervision of some body of assets or some enterprise is called for - supervision beyond that required in the typical sheriff's sale. For a number of centuries the courts have engaged in the sort of long-term supervision of affairs that has occasioned comment in analyses of recent institutional cases. Moreover, in some instances they have created specialized tribunals, or specialized branches of general tribunals, to conduct such supervision. Because of this specialization, those of us who do not deal frequently with particular substantive areas tend to forget that they too are parts of the law and that their courts are parts of the judicial universe. A survey of some of the activities in these areas may help to dispel the impression that supervisory burdens

${ }^{79}$ See pp. ${ }^{668-70}$ supra. 
assumed in institutional cases present a dramatically new phenomenon.

I. Probate and Trusts. - The culture from which we derive our law has, at least since the later middle ages, placed great emphasis on the power of testamentary disposition. ${ }^{80}$ Accordingly, courts have developed a series of substantive rules and special procedures to perform the task of preserving the decedent's assets, satisfying the claims of his creditors and the taxing authorities, and distributing the remainder to the beneficiaries. ${ }^{81}$

Probate administration provides examples of courts involved not only in the securing of money or the conversion of assets from some other form to money; probate also frequently requires that the court supervise the conduct of some continuing enterprise to preserve certain assets pending their final disposition. Thus, while the personal representative of the decedent may operate the decedent's business, ${ }^{82}$ incur debts, ${ }^{83}$ invest estate funds, ${ }^{84}$ enter into leases, ${ }^{85}$ and buy and sell property, ${ }^{86}$ in appropriate circumstances he may need a court's approval to do so. ${ }^{87}$ Judges supervise businesses - not as an extraordinary event, but as an incident of the entirely routine probate of an estate.

In recent decades considerable efforts have been made to reduce court involvement in the administration of estates. ${ }^{88}$

${ }^{80}$ See S. Milsom, Historical Foundations of the Common LaW 140 (1969); 2 F. Pollock \& F. Maitland, The History of English Law 3I3, 363 (2d ed. reissued, I968).

${ }^{81} \mathrm{~J}$. Dukeminier \& S. Johanson, Family Wealth Transactions I083-9x (2d. ed. $x 978$ ).

82 See, e.g., Uniform Probate Code $\S 3-715(24)$; Cal. Prob. Code $\$ 572$ (West Supp. r979).

${ }^{83}$ See, e.g., Uniform Probate Code § 3-715(I6); Cal. Prob. Code $\S 830$ (West Supp. 1979).

${ }^{84}$ See, e.g., Uniform Probate Code $\S 3-715(5)$; Cal. Prob. Code $\S 584.5$ (West Supp. 1979).

85 See, e.g., Uniform Probate Code § 3-715(9); Cal. Prob. Code § 840 (West Supp. 1979).

${ }^{86}$ See, e.g., Uniform Probate Code § 3-715(6); CaL. Prob. Code $\S \S 750,854$ (West 1956).

${ }^{87}$ See, e.g., Uniform Probate Code \$§ 3-715(24)(ii), 3-501 to -505; Cal. Prob. CoDE $\S \S 578,578 \mathrm{a}, 584,584.3,584.5,584.6,588,591.2$ (West 1956, Supp. 1978); $c f$. UNIFORM PROBATE CODE $§ 3-704$ (representative may invoke court's jurisdiction to resolve questions concerning the estate).

${ }^{88}$ For example, the Uniform Probate Code envisions most of the administration of the estate as taking place without the need for court approval. See UNIForm Probate CODE $\S \S 3-704,3-715$. "Overall, the system accepts the premise that the Court's role in regard to probate and administration, and its relationship to personal representatives who derive their power from public appointment, is wholly passive until some interested person invokes its power to secure resolution of a matter." Id., General Comment to article 3 3nline -- 93 Harv. L. Rev. 482 1979-1980 
The approach taken by the Uniform Probate Code and adopted by several states eliminates the need for court supervision of most uncontested aspects of estate administration. ${ }^{89}$ These statutes authorize a wide range of activity by the personal representative without direct judicial supervision. Once an interested party complains, ${ }^{90}$ however, the court becomes involved in much the same way as is typical under the "unreformed" statutes. ${ }^{91}$

Under the "reformed" systems, the court is in much the same position as a judge in an institutional case after the plaintiff's pleadings are filed. But it is far easier to obtain judicial intervention in probate than in institutional cases. A court will determine whether the affairs of an estate require judicial administration as soon as the request for such a determination is made; the petitioning party need not prove that the person currently managing the estate has already breached his fiduciary responsibilities. Yet the plaintiff in an institutional case must demonstrate that a substantive violation has occurred before the question of remedy is ever reached. Only at that point will a court consider whether judicial supervision of the institution is necessary to remedy the wrong.

The law of trusts has long recognized that the wealthy find it useful to divest themselves - at least partially - of control of their assets even before death forces them to do so. The courts have played a significant role in supervising the management of these trust assets. ${ }^{92}$ Trusts rest on the assurance that courts will be willing to step in to supervise the disposition and management of property by trustees who may be tempted to divert resources to themselves. ${ }^{93}$ To prevent trustee improprieties, courts have developed a body of substantive law. designed to force the trustee to manage the assets at least as carefully as if they were his own. ${ }^{94}$ Courts enforce this fiduciary duty rule by insisting that the trustee render periodic

${ }^{89}$ See note 88 supra. Thirteen states have either adopted the code or similar provisions. See J. Dukeminier \& S. Johanson, supra note 8I, at II25 \& nn. 45, 46.

90 See Uniform Probate Code § 3-105.

91 See Uniform Probate Code $\S 3-502 ; c f$. Cal. Prob. Code $\S 59$ r.I (West Supp. 1979) (once an interested party complains, unsupervised administration is permitted only after personal representative petitions for such authority from the court).

92 See generally $T$. PlucknetT, A Concise History of the COMmon LaW 598-602 (5th ed. I956); S. Milsom, supra note 80, at 205-10.

93 Indeed, it would not be a great exaggeration to say that the trust became possible only when Chancery was prepared to compel the person we would now call the trustee to deal with the property in question for the benefit of the beneficiary generally by conveying to the beneficiary land held for his use. T. PLUCKNETT, supra note 92 , at 599 .

94 See Restatement (Second) of Trusts § 174 (1979); J. Dukeminier \& S. JohANSON, supra note 8I, at II56-207; cf. UNIFORM PROBATE CODE $\$$ 7-302, 
accountings, ${ }^{95}$ and by requiring judicial approval of certain unusual or inherently suspicious transactions. ${ }^{96}$ These procedures involve the courts in the administration of complex and large bodies of assets on a continuing basis, and require judicial evaluation of the loyalty of the trustee, the prudence of an investment, and the propriety of self-dealing that the trustee claims will benefit the beneficiary.

A few examples reveal the complexity and length of some trust and probate matters. The disposition of one $\$ 17,000,000$ estate took twenty-three years, required consideration of 26,000 claims, and led to 390 volumes of testimony. ${ }^{97}$ Another will contest involved 2,303 fortune hunters. ${ }^{98}$ Painter Mark Rothko's estate was in litigation in New York's courts for many years and required judicial construction of Rothko's will, ${ }^{99}$ judicial determination of the adequacy of the price received for some of Rothko's paintings, ${ }^{100}$ judicial authorization to take action in a foreign country to preserve the estate, ${ }^{101}$ and judicial consideration of the ultimate administrative question, whether the trustees of Rothko's property

comment (the standard of care required to hold a trustee to his duty is that "observed by a prudent man dealing with the property of another" and is derived from judicially developed standards).

95 See G. Bogert \& G. Bogert, The Law of Trusts and Trustees $\$ \S 965-$ 968 (2d ed. I962 \& Supp. 1978). In recent years various reforms have made periodic accountings a matter of choice rather than a requirement. Id.; UNIFORM PROBATE CODE $\$ 7-303$. However, any beneficiary may petition the court for an order compelling an accounting, and the trustee may voluntarily make a formal accounting to protect himself from later attack. N.Y. SuR. CT. PRoc. LAw \$\$ 2206-2208 (McKinney 1967). As a result, even in jurisdictions that have abolished mandatory accounting to a court, the protection offered by such accountings means that trustees will regularly ask courts to approve their dealings. See Kehoe, Allowance of Probate Accounts, 59 MASS. L.Q. 315 (1975).

${ }^{96} \mathrm{See}$ ReSTATEMENT (SECOND) OF TRUSTS § 192, comment d at 259 (1979); id., comment $\mathrm{e}$ at 260 ; $i d$., comment $\mathrm{b}$ at 220 . Together these sections allow a trustee to protect himself from liability when operating in areas of uncertainty concerning the administration of the trust.

${ }^{97}$ See In re Garrett's Estate, 372 Pa. 438, 94 A.2d 357, cert. denied, 345 U.S. 996 (1953). See also New Orleans v. Gaines' Adm'r, 138 U.S. 595 (1891) (70 years of effort to establish will); Old Colony Trust Co. v. Rodd, 356 Mass. 584, 254 N.E.2d 886 (I970) (trustee seeking approval of 4 oth and 4Ist accountings); Haddock v. Boston \& M.R. Co., 146 Mass. I55, I5 N.E. 495 (I888) (estate in litigation for 63 years).

${ }^{98}$ In re Estate of Wendel, I43 Misc. 480, 257 N.Y.S. 87 (Sur. Ct.); 143 Misc. 817, 257 N.Y.S. 97 (Sur. Ct.); I44 Misc. 467, 259 N.Y.S. 260 (Sur. Ct. 1932); 146 Misc. 260,262 N.Y.S. 4 I (Sur. Ct.); 148 Misc. 884,267 N.Y.S. 33 (Sur. Ct. 1933); 159 Misc. 443,287 N.Y.S. 893 (Sur. Ct. I936).

${ }_{99}$ In re Estate of Rothko, 77 Misc. 2d I68, 352 N.Y.S.2d 574 (Sur. Ct. 1974), aff'd, 47 A.D.2d 623, 366 N.Y.S.2d 6ro (1975).

100 See L. Seldes, The Legacy of MARK Rothko 277-78 (1978).

$101 \mathrm{Id}$. at $283-89$. 
should be replaced. ${ }^{102}$ In short, it appears that the courts have been far more willing to supervise the trustees of funds than of souls.

2. Bankruptcy. - Modern bankruptcy procedures spring both from the demise of the view that insolvency is the result of a moral failure ${ }^{103}$ and from the desire to reduce the nasty squabbling of too many creditors for too few assets. ${ }^{104}$ Bankruptcy law tries to ensure that at least some portion of each creditor's demands are satisfied, and helps restore hopeless insolvents to the ranks of the economically viable. In the process of applying this law, courts have become involved in operating the Penn Central Railroad ${ }^{105}$ as well as many other considerably more modest enterprises.

Bankruptcy administration requires the courts to play two roles. First, courts assist in the operation of an enterprise prior to liquidation and distribution of assets to the creditors; the court aids a trustee or receiver whose role is similar to that of the personal representative of a decedent who operates a business until the court can approve a plan of sale. Second, in more complex cases, the courts attempt to reestablish the business on a different financial footing, to reorganize it in a manner both fair to its creditors and financially sound. ${ }^{106} \mathrm{It}$ is worth stressing that courts routinely ${ }^{107}$ handle such difficult reorganization cases, passing on aspects of financial structure that are unlikely to be second nature to most judges. They

${ }^{102}$ In re Estate of Rothko, 43 N.Y.2d 305, 372 N.E.2d 29I (1977). For other judicial proceedings relating to the Rothko estate and details of the proceedings referred to in text, see L. SELDES, supra note I00, at I2I, 185-88, I92-282, 290-9I, $306-07,33 \mathrm{I}$.

${ }^{103}$ See Levinthal, The Early History of English Bankruptcy, 67 U. PA. L. REv. I, I8-20 (IgIg).

${ }^{104}$ See G. GlenN, Liquidation §§ 5-7 (I935).

${ }^{105}$ See generally Blanchette v. Connecticut Gen. Ins. Corp., 4I9 U.S. 102 (1974) (Regional Rail Reorganization Act Cases); Baker v. Gold Seal Liquors, Inc., 4r7 U.S. 467 (1974); New York, N.H. \& H.R.R. First Mortgage $4 \%$ Bondholders Comm. v. United States, 399 U.S. 392 (1970) (New Haven Inclusion Cases); Baltimore \& O.R.R. v. United States, 389 U.S. 486 (I968) (Penn-Central Merger and N \& W Inclusion Cases); In re Penn Central Transp. Co., 494 F.2d 270 (3d Cir.), cert. denied, 4I9 U.S. 883 (I974); In re Penn Central Transp. Co., 484 F.2d I300 (3d Cir. 1973), cert. denied, 4I5 U.S. 95I (1974); In re Penn Central Transp. Co., 484 F.2d 323 (3d Cir.), cert. denied, 4I4 U.S. I079 (1973); In re Penn Central Transp. Co., 474 F.2d 832 (3d Cir. 1973); In re Penn Central Transp. Co., 468 F.2d I222 (3d Cir. I972); In re Penn Central Transp. Co., 458 F. Supp. 1234, 1346, I357, I364 (E.D. Pa. I978); In re Penn Central Transp. Co., 325 F. Supp. 302 (E.D. Pa. I97I).

106 See, e.g., W. Blum \& S. KaPLAN, CoRPorate REAdJUSTMENTS AND REORGanizations I84-86 (1976). See generally Bankruptcy Reform Act of 1978, Pub. L. No. 95-598, 92 Stat. 2549 (codified at II U.S.C. \$§ IOI-IO9, 30I-366, 50I-554, 701-766 (Supp. 1979)).

${ }^{107}$ See generally W. BLUM \& S. KAPLAN, supra note ro6, at $184-86$. 
struggle through with a little help from the briefs, but at least since the I930's there have not been many suggestions that judicial supervision of these complex financial transactions is illegitimate. ${ }^{108}$

\section{Statutory and Common Law Bases for Judicial Activism: Why the Old Seems New}

Critics recognizing the similarities set out above between the old and the new litigation might nevertheless contend that the judicial action taken in many institutional cases cannot be justified absent legislative authorization. In traditional litigation, such critics might claim, courts dealing with litigant intransigence or remedial supervision were explicitly guided by statutory commands. The new litigation breaks step with this tradition, however, since it lacks the underlying statutory basis for judicial activism. ${ }^{109}$

Though often unarticulated, this statutory-nonstatutory distinction lies at the heart of much of the commentary on the new litigation. The argument from statutory authorization, however, is not compelling. While express statutory support for some aspects of the remedial decrees in institutional cases is lacking, the statutory basis for the new litigation is not nearly so weak as the critics would have us believe. Moreover, the statutory-nonstatutory dichotomy simply fails to distinguish cases in which courts have assumed administrative burdens from those in which courts have not done so. But even if the statutory basis for judicial activism is less than firm in some contexts, the case against the new litigation is not made. Where statutory authority for the new litigation is absent, the real question is whether the courts should nonetheless reach out on their own, as they have so often done in the past. ${ }^{110}$ In one sense lack of statutory authorization marks the beginning of an inquiry, not the end of it.

I. Statutory Bases for the New Litigation. - Institutional litigation is frequently brought under a civil rights statute,

${ }^{108}$ See United States Securities \& Exchange Commission, Report on the Study and Investigation of the Work, Activities, PERsonnel and Functions of Protective and Reorganization Committees (1936-r937). See also $1 \mathrm{H}$. Remington, A Treatise on the BankRuptcy LaW of the UNited STATES $\$$ is (5th ed. 1950). This is not to suggest that creditors are always content with what is done for (or to) them in reorganization proceedings. But creditor displeasure, which is, of course, mixed with satisfaction on the part of those who believe they are getting more in the reorganization than they would in its absence, has not been taken seriously as a basis for keeping the courts out of business reorganizations.

${ }^{109}$ See, e.g., Frug, supra note 2, at 732-34.

${ }^{110} \mathrm{See}$, e.g., Bivens v. Six Unknown Named Agents of Fed. Bureau of Narcotics, 403 U.S. 388 (I97I); In re Debs, 158 U.S. 564 (1895). 
section $1983,{ }^{111}$ which instructs the nation's courts to grant legal and equitable relief for violations of federal constitutional and statutory law. The critics of institutional litigation have not objected to the substantive rights being enforced in section I983 cases, ${ }^{112}$ even though recent years have seen a number of proposals to limit the substantive scope of the statute. ${ }^{113}$ Nor have the critics of the new litigation suggested that the scope of the statute's broad remedial provision be restricted. Nonetheless, they find the judicial application of these provisions objectionable.

But if the facts establish the underlying cruel and unusual punishment or due process claim, the burden of proof should be on those who suggest that courts should not attempt fully to remedy the constitutional violations. We do not claim that section I983 mandates all the various remedies adopted in the institutional cases. But the underlying rights and the openended text of section 1983 suggest that many institutional cases should be viewed as judicial efforts to enforce a congressional mandate rather than as attempts to wrest power from the legislature. ${ }^{114}$

Although critics emphasize the displacement of state by federal law in institutional litigation, it is also important to recognize that some of the remedies in the institutional cases often vindicate express state policies. ${ }^{115}$ For example, in Halder v. Pennhurst State School and Hospital, ${ }^{116}$ a Pennsylvania mental institution case, the federal district court relied in part upon a state statutory right to minimally adequate treatment in ordering substantial relief. In Anderson $v$. Redman, ${ }^{117}$ a Delaware prison case, the court found conditions

${ }^{111} 42$ U.S.C. \& 1983 ( 1976$)$.

112 See, e.g., Frug, supra note 2; Nagel, supra note 2.

113 See, e.g., H. Friendly, Federal JuRISdiction 9i-96 (I973); Shapo, Constitutional Tort: Monroe v. Pape and the Frontiers Beyond, 60 Nw. U.L. REv. 277 (r965); Note, Limiting the Section I983 Action in the Wake of Monroe v. Pape, 82 HARV. L. REV. I486 (1969).

114 We do not mean to argue that there has been an uninterrupted use of $\S 1983$ for the past roo years. Rather, the new use of $\S 1983$ for relief in institutional cases derives from the substantive development of constitutional law in the I95o's and I960's. The historical discontinuity came not so much because $\S$ I 983 was clarified, see Monroe v. Pape, 365 U.S. I67 (I96I), but because constitutional rights entitled to vindication were greatly expanded. See generally Note, supra note II3. Even in the absence of $\S 1983$, results in institutional cases in recent years might have rested on direct actions under the Constitution.

115 At least one major prison case was decided by a state court. See Hendrick v. Jackson, ro Pa. Commw. Ct. 392, 309 A.2d 187 (r973), modified, 457 Pa. 405, 32 I A.2d 603 (I974).

116446 F. Supp. I295, I322-23 (E.D. Pa. I977).

117429 F. Supp. I105, I122 (D. Del. I977). 
that violated state statutes and administrative regulations. A number of other institutional cases have state law overtones. ${ }^{118}$ And in school desegregation cases, a category of litigation so familiar that one tends to assume it has its foundation in Brown v. Board of Education, ${ }^{119}$ there are state laws involved. Craweford v. Board of Education, ${ }^{120}$ a school desegregation case tried in state court, finds its substantive basis in the California as well as the Federal Constitution.

But even if it is conceded that there is no statutory authorization for much of the new litigation, there is a nagging inconsistency in the criticism of such cases. To the extent that institutional litigation is viewed as questionable because judges lack the capacity and resources to make policy for large institutions and to supervise their administration, it is difficult to understand why the existence of a relevant statute would make a difference. A legislative enactment does not magically enhance judges' administrative and policymaking abilities. The judges of the Railroad Reorganization Court do not suddenly become vested with detailed knowledge about locomotives and debt-equity ratios merely because they proceed under a statutory scheme. Yet, for the most part, critics of prison and mental hospital cases are strangely silent about judicial capacity to run large businesses, estates, or trusts. Arguments about statutory authorization obscure the more fundamental issue of whether judges actually have the capacity intelligently to authorize broad remedial measures.

2. The Common Law Origins of Other Burdensome Cases. - Statements about the novelty of courts assuming complex administrative tasks without statutory authority also encounter a formidable obstacle of historical fact. In many instances courts developed elaborate judicial supervision of enterprises long before present codifications were enacted. To be sure, in

\footnotetext{
118 Dillard v. Pitchess, 399 F. Supp. 1225, 1239-40 (C.D. Cal. 1975); Battle v. Anderson, 376 F. Supp. 402, 4I4, 418, 423 (E.D. Okla. 1974), aff'd, 564 F.2d 388 (roth Cir. 1977); Welsch v. Likins, 373 F. Supp. 487 (D. Minn. 1974), aff'd, 550 F.2d II22 (8th Cir. 1977); Gates v. Collier, 349 F. Supp. 881, 889-90, 894 (N.D. Miss. I972), aff'd, 50r F.2d I29I (5th Cir. I974); Taylor v. Sterrett, 344 F. Supp. 41I, 4I7-18 (N.D. Tex. I972), aff'd, 499 F.2d 367 (5th Cir. I974), cert. denied, 420 U.S. 983 (r975); Jones v. Wittenberg, 323 F. Supp. 93, 98 (N.D. Ohio); 330 F. Supp. 707 (N.D. Ohio I971), aff'd sub nom. Jones v. Metzger, 456 F.2d 854 (6th Cir. 1972). The Boston school desegregation case has occurred in a state in which state law may well require greater efforts toward racial balance than federal law. See MASS. GEN. LAwS ANN. ch. 7I, $\S 37 \mathrm{C}, 37 \mathrm{D} ;$ id. ch. I5, $\S$ II, IJ, IK (West); Morgan v. Kerrigan, 379 F. Supp. 410, 4I7-20 (D. Mass. 1974), aff'd, 509 F.2d 580 (1st Cir.), cert. denied, 42 I U.S. 963 (1975).

119347 U.S. 483 (1954).

${ }^{120}$ I7 Cal. 3d 280, 296-97, 55 I P.2d 28, 39, I30 Cal. Rptr. 724, 734-35 (1976).
} 
some of the instances we have described, courts have developed elaborate remedies only pursuant to statutory authority. One strong instance of such a pattern is straight or liquidating bankruptcy. The first judicial enforcement of bankruptcy proceedings came in the wake of statutory authorization. ${ }^{121}$ Yet even here it appears that legislatures thought courts would be able to devise appropriate procedures for the marshaling and distribution of assets; the early acts assumed that courts would take considerable initiative in this area. ${ }^{122}$

Courts have developed and administered, almost entirely on their own, significant bodies of remedial law requiring them to engage in continuing supervision of enterprises. Perhaps the best example of this judicially developed supervisory remedy is the law of trusts. The beneficiary's interest in the use "was a wholly unique form of ownership which the chancellor had ... . developed from a conscientious obligation of a very personal kind." 123 The Chancellor stood ready to enforce the duties created by a trust, including the quite common duty of establishing and faithfully running religious institutions. ${ }^{124}$ It can scarcely be said that a modern exercise of equitable power to correct conditions in a prison, hospital, or school is a newfangled addition to the judicial arsenal. Nor can it be said to be more burdensome; after all, in Wyatt and Holt the courts were not required to secure the plaintiffs' immortal salvation, but merely to assure that they should not attain that desirable state prematurely in consequence of their keepers' neglect.

Similarly, in probate cases, the ecclesiastical courts, whose powers were enforced and later assumed by Chancery, exercised "a strict supervision over executors, calling for accounts, examining them, and directing the work of administration generally." ${ }_{125}$ Moreover, the church courts did so without the benefit of any particularized legislation, implying the powers required for elaborate supervision from their jurisdiction over wills in general. Ecclesiastical jurisdiction over probate matters, therefore, rested as much on an abdication of responsibility by the king's courts as on any specific statutory authority. ${ }^{126}$

121 See, e.g., I H. REMINGTON, supra note I08, § 2.

122 Id. §§ 3-7.

1234 W. Holdsworth, A History OF ENGLish LAW 43I, 433 (ig24).

124 For example, in 1404 , the Chancellor was prepared to enforce the directions of one Sir William Heron "that [the trustees] make or else perform, an hospital that is begun, of six or four poor men at least, and a priest in a chantry by wise and discreet ordinance and discretion perpetual for to govern them." Id. at 439 n.5.

125 T. PLUCKNETT, supra note 92, at 742.

126 Id. at 740 . 
In addition, the courts of law made use of administrative prerogative writs. ${ }^{127}$ The writ of certiorari, for instance, was in its origin "essentially a royal demand for information . . . used for general governmental purposes." 128 The ad hoc, supervisory nature of the writ demonstrates the boldness of this early form of judicial activism. ${ }^{129}$ Certiorari was a tool of what we would now call administrative law, or perhaps simply administration, since the "courts" to which it was regularly directed would now be classified as administrative agencies. ${ }^{130}$ Mandamus was also in its origin a tool of administrative supervision. So routine was its use that courts for some time seemed to perceive it as a command to some royal agent rather than as a separate writ. ${ }^{131}$ The courts used these new writs as commonplace instruments of the most ordinary tasks of administrative supervision. It is only in comparatively recent centuries that such "extraordinary" writs have been transformed from the stuff of everyday political life into exotics of the legal firmament. If one objects to judicial activism in institutional litigation, then, it must be on grounds other than novelty: the novel idea is that courts should not concern themselves with the king's oppressed subjects. ${ }^{132}$

The phenomenon of judicial participation in the administration of complex institutions without prior statutory mandate is not limited to England before the twentieth century. The American colonies and their successor states embraced much of the British law of trusts, estates, and writs in their common law systems. ${ }^{133}$ And in the relatively recent American past,

127 E. Henderson, Foundations of English Administrative LaW I-5 (I963);

T. PluCKNETT, supra note 92, at 173 .

128 de Smith, The Prerogative Writs, II CAMB. L.J. 40, 45 (1951). See also E. HENDERSON, supra note 127 , at 89-9I ("[C]ertiorari ... [f]or many judicial and administrative purposes . . . was the medieval equivalent of 'Get me the file on such a matter.'").

129 A typical writ stated that "the King wishes to be more fully informed of allegations of extortion made by his subjects in Lincoln, and therefore appoints commissioners to inquire into them." de Smith, supra note 128 , at 45 . See also E. HENDERSON, supra note 127 , at 90 .

${ }^{130}$ The Commissioners of Sewers and the Courts of the Forest are examples of "courts" we would now call administrative agencies. de Smith, supra note 128, at 46.

${ }^{131}$ Id. at 50 (citing Jenks, The Prerogative Writs in English Law, 32 YALE L.J. $523,530(1923))$. When the writ finally developed into something recognizably like the modern form, it was strikingly and specifically for administrative purposes. E. HENDERSON, supra note 127 , at 62 .

132 Edith Henderson made the point in speaking of the development of the writ of mandamus in the early seventeenth century: "[T] said nothing to explain why King's Bench could do this, beyond the bare generality that an injustice had been done and it ought to be set right." E. HENDERSON, supra note 127 , at 62 .

${ }^{133}$ See, e.g., L. Friedman, A History of AMERICAN LAW 57-59 (1973). 
courts, without direct statutory authority, have become deeply involved in the affairs of that most complex institution - the modern business corporation. Both the newly enacted and the recently superseded bankruptcy acts contain detailed instructions for assisting financially troubled businesses. ${ }^{134}$ It is easy to forget, however, that these provisions, unlike much of the rest of bankruptcy law, derive from court-made bankruptcy law predating the country's first business reorganization legislation. Those first statutes ${ }^{135}$ built upon reorganization practices developed by federal courts without statutory guidance during late nineteenth- and early twentieth-century equitable receiverships. ${ }^{136}$ In the course of such receiverships courts involved themselves in the minute details of running large complicated businesses. ${ }^{137}$ Neither Britons nor Americans should find judicial supervision of complex institutions novel.

\section{E. The "New" Litigation and Historical Continuity}

Comparison of the new litigation with other litigation of various vintages casts doubt upon the novelty of modern American institutional cases. From one perspective, what is said to be new in these cases is really only a response to problems of intransigence and complexity that the law has dealt with in "extraordinary" ways for centuries. Nor does detailed supervision of complex, continuing matters signal the dawn of a new judicial day. ${ }^{138}$ The two paradigmatic insti-

${ }^{134}$ See Bankruptcy Reform Act of 1978 , §§ IroI-II46, II U.S.C. $\S \S$ IIOI-II46 (Supp. 1979). See also II U.S.C. §§ 501-799 (1976) (old bankruptcy act). Most provisions of the new act took effect on October I, I979. Bankruptcy Reform Act of 1978, Pub. L. No. 95-598, § 402(a), 92 Stat. 2682 (I978).

${ }_{135}$ The first major reorganization provisions, the predecessors to the Bankruptcy Reform Act of 1978 , II U.S.C. \$§ II6I-II74 (Supp. I979), dealt only with railroads and were added to federal law in I933. Act of Mar. 3, I933, Pub. L. No. 72-420, ch. 204, § 77, 47 Stat. 1467,1474 (1933). A provision for reorganization of other corporations was added in I934. Act of June 7, I934, Pub. L. No. 73-296, ch. 424, $\S 77$ B, 48 Stat. 912 (I934).

136 See REPORT OF THE COMMISSION ON THE BANKRUPTCY LAWS OF THE UNITED States, H.R. Doc. No. 93-I37, 93d Cong., Ist Sess., pt. I, at 238-39 (1973); G. GLENN, supra note 104, § 430, at 606-07. The old equity receiverships soon were displaced by the statutory alternatives. W. BLUM \& S. KAPLAN, supra note I06, at 221-22. Doctrines governing executory contracts under the bankruptcy statutes are derived from equity receivership cases. See Countryman, Executory Contracts in Bankruptcy (pt. 2), 58 MrNN. L. REV. 479, 530 (1974).

137 See G. GLENN, supra note I04, $\S \mathrm{I62}$, at 270 (corporate directors could take no action relating to the estate being administered without court order). Ironically, the exercise of equity receivership jurisdiction seems to have originated with a state court. Id. § 159 , at 265-66.

138 Owen Fiss has argued that in what he calls "structural injunctions" one sees a new procedural tool which, in his words, is a decree "seeking to effectuate the reform of a social institution." $O$. FIss, supra note 4, at 9. He identifies it as the 
tutional litigation cases described above, Wyatt v. Stickney ${ }^{139}$ and Holt v. Sarver, ${ }^{140}$ represent substantial judicial intrusion upon legislative and executive prerogatives. Yet it should be noted that the courts in those cases only began to prescribe the specific details of institutional reform when it became clear that state and local officials were not likely to cooperate. ${ }^{141}$

procedural legacy of the civil rights era, in which not just an isolated private or public wrong but an entire social system needed undoing. Fiss argues that memories of the Progressive Era, when courts used the injunction as a tool in their rearguard action against labor organizations and the emerging welfare state, have combined with traditional equity doctrines developed before merger to render courts unjustifiably chary of using injunctions. He asserts that the cautious stance induced by these legacies cannot be justified and that courts should abandon a hierarchical conception of remedies, in which injunctive relief comes into play only when the plaintiff can show that the legal remedy is inadequate.

For the most part Fiss' argument is consistent with the point we are asserting. Whether or not the structural injunction ought to be used only as a last resort, the fact is that up to the present that is how it has been used; for our purposes it is sufficient to show that the courts' actions are explicable even in the traditional terms Fiss criticizes. We need not bear the heavier burden he assumes in urging courts to move beyond such a conception.

In one respect, however, we do take issue with Fiss, less with his normative argument than with his description of the injunction's history. He starts from the proposition that the structural injunction is a new development, id. at 8, with antecedents in railroad reorganizations at the turn of the century and more recently in antitrust divestiture cases, but with no significantly more distant ancestors. We have no quarrel with the assertion if it is limited strictly to injunctions; but we contend that courts have for considerably longer than that been employing various devices to supervise the workings of complex institutions. The injunction must be seen as one of a number of judicial devices for dealing with losing litigants; by viewing the injunction as a single device among many - though a device with some special characteristics - one perceives the links between the modern structural injunction and some much more venerable devices. See also pp. 485-91 supra.

139325 F. Supp. 78 I (M.D. Ala.), hearing on standards ordered, 334 F. Supp. I34I (M.D. Ala. I97 r), enforced, 344 F. Supp. 373 (M.D. Ala.); 344 F. Supp. 387 (M.D. Ala. 1972), aff'd sub nom. Wyatt v. Aderholt, 503 F.2d 1305 (5th Cir. 1974). 140300 F. Supp. 825 (E.D. Ark. 1969); 309 F. Supp. 362 (E.D. Ark. 1970), aff'd, 442 F.2d 304 (8th Cir. 197I).

141 Much of what seems unusual in Wyatt resulted directly from the defendant's intransigence. Even though conditions were clearly disgusting, and even though the court felt the conditions were unconstitutional, 325 F.Supp. at $784-85$, the initial remedial order in Wyatt $v$. Stickney left the reformation of Bryce Hospital almost entirely to the discretion and good faith of state officials. Only after it became clear that no relief would be forthcoming voluntarily did the court become involved in the specifics of institutional reform. See pp. 468-70 supra.

The story in Holt $v$. Sarver is similar. The disgusting conditions found by the court did not lead to an order for immediate changes in the Arkansas prison system to comply with the court's notion of civilized confinement. There were no immediate threats of contempt citations. For many months the court left the remedying of prison conditions to state authorities. See pp. 470-72 supra. Eventually it became clear that Arkansas would not clean up its own house. Only then did the court start to render detailed decrees that began to intrude on the policymaking and administrative functions of Arkansas officials - but even these decrees never achieved the specificity of those in Wyatt. 
Assuming that the conditions under review by the courts in those cases were unconstitutional, it is difficult to imagine how a responsible court could have avoided issuing an aggressive and detailed decree.

In many cases characterized as institutional, the judicial role was far less intrusive. Some cases considered to be part of the new litigation are little more than judicial opinions blessing settlements negotiated by the parties. ${ }^{142}$ At least one decision adopted the remedial scheme proposed by the defendant health authorities instead of that proposed by plaintiff patients. ${ }^{143}$ In such cases it can scarcely be said that courts are seizing power from reluctant officials. ${ }^{144}$ In another case, the only issue decided was drastic overcrowding in a state prison system. The district court allowed two years of study before ordering measures calculated to reduce the inmate population to acceptable levels; it then gave the state another two years to achieve the required population levels. ${ }^{145}$ In many cases in which judicial intervention occurs, the intervention is at least initially mild, allowing the defendants to devise programs that will square institutional conditions with constitutional requirements. ${ }^{146}$ These are not courts hell-bent on remaking society.

Admittedly, courts should pause before ordering relief that will involve judges in continuous supervision of unfamiliar

142 See, e.g., Gauthier v. Benson, I Mental Disability L. ReP. (CCH) I22 (D. Mass. 1976); Inmates of Henry County Jail v. Parham, 430 F. Supp. 304 (N.D. Ga. 1976). See also New York State Ass'n for Retarded Children, Inc., v. Carey, 393 F. Supp. 715 (E.D.N.Y. 1975) (decree resulted from extensive negotiations between the parties).

143 Saville v. Treadway, 404 F. Supp. 430 (M.D. Tenn. 1974).

$144 \mathrm{As}$ is the case with any negotiated settlement, it might be argued that the agreement is reached merely because of the threat of judicial action - and therefore, that the judiciary is, in some attenuated sense, seizing power. See generally Mishkin, supra note 2, at 957. Such cases certainly represent less of an intrusion by the judiciary than cases in which the details of the relief granted spring from the district judge's imagination. The relief ordered in negotiated settlements is agreed to by the defendants and, at least presumptively, is believed by them to be achievable or desirable.

${ }^{145}$ Costello v. Wainwright, 397 F. Supp. 20 (M.D. Fla. 1975), aff'd, 525 F.2d I239 (5th Cir.), vacated and remanded on rehearing, 539 F.2d 547 (5th Cir. I976) (en banc), rev'd per curiam on other grounds, 430 U.S. 325 (1977).

${ }^{146}$ In addition to Holt and Wyatt, see Campbell v. Magruder, 580 F.2d 521, 542 (D.C. Cir. 1978); Nelson v. Collins, 455 F. Supp. 727 (D. Md.), modified sub nom. Johnson v. Levine, 588 F.2d 1378 (4th Cir. r978); Chapman v. Rhodes, 434 F. Supp. ro07 (S.D. Ohio 1977); Inmates of Henry County Jail v. Parham, 430 F. Supp. 304 (N.D. Ga. 1976); Dillard v. Pitchess, 399 F. Supp. I225 (C.D. Cal. 1975); Saville v. Treadway, 404 F. Supp. 430 (M.D. Tenn. I974); Collins v. Schoonfield, 344 F. Supp. 257 (D. Md. 1972); Brenneman v. Madigan, 343 F. Supp. I28 (N.D. Cal. 1972); Goldstein, supra note $\mathrm{I}$, at $65 \mathrm{n} .32 \mathrm{I}$ (courts issue detailed remedial orders in prison cases only after litigant displays intransigence); id. at $66 \mathrm{n} .323$ (schools placed in receivership infrequently and only after long delay). 
institutions. Holt, Wyatt, and other $\operatorname{cases}^{147}$ indicate that courts do pause. But once intransigence and the complex nature of the institutions involved make detailed decrees and some level of supervision inevitable, courts are not on nearly such new ground as the commentary suggests. Courts often have had to monitor executors and various kinds of trustees, including some operating large, complex businesses. Moreover, courts have shown willingness to participate in the continuous supervision of large enterprises for reasons no more compelling than that such arrangements are useful to those who have more property than they can conveniently manage or dispose of themselves. By comparison, it does not seem to be an outrageous abuse of judicial authority for courts to supervise state and local authorities in order to ensure that these officials protect the constitutional rights of prisoners, patients, and school children. Courts should be able to demand sufficient alteration in the supervision of mental patients to keep them from drowning in their own vomit. ${ }^{148}$

\section{Constitutional Limitations and the New Litigation: SEPARATION OF POWERS AND FEDERALISM}

The roots of institutional litigation thus far discussed involved mostly private litigation and common law adjudication. The continuity of such traditional litigation and modern institutional cases cannot completely answer the critics. For separation of powers and federalism doctrines suggest specifically American concerns not at risk in a tradition of English, private litigation. ${ }^{149}$ It is to an examination of these new concerns and their bearing on institutional litigation that we now turn.

In so doing, however, we want to make two preliminary points. First, our goal is the same as that which we undertook in placing institutional litigation in the context of older judicial traditions: we do not take our burden to be that of demon-

${ }^{147}$ See, e.g., Morgan v. McDonough, 540 F.2d 527 (Ist Cir. 1976), cert. denied, 429 U.S. 1042 (1977). See also Frug, supra note 2, at 762-67 \& n.277 (receiver appointed in Boston desegregation case because of massive resistance to desegregation); The Wyatt Case, supra note 4, at 1349-50 n.56.

148 See Wyatt v. Stickney, 344 F. Supp. at 393-94 \& n.13. See also The Wyatt Case, supra note 4, at 1349 n.56 (quoting Brief of Amici Curiae the American Ass'n on Mental Deficiency et al. at 5, Wyatt v. Aderholt, 503 F.2d 1305 (5th Cir. 1974).

149 See generally R. BRIDWell \& R. WhitTen, The Constitution AND THE COMMON LAW II5 (1977) (private character of common law adjudication precludes its intrusion upon separation and federalism principles). 
strating that principles of federalism or separation of powers require the results reached in the institutional cases. We want only to show that nothing in the twistings of these doctrines creates any fatal obstacles to such litigation.

Second, we should make clear our general stance toward the doctrines discussed in the following sections. Separation of powers and federalism are terms used to describe existing allocations of power among parts of the government. Such divisions of power spring from historical circumstances in which highly distinctive regional societies feared both domination by a central government and domination of the central government by any one of its branches. Many regions feared that the federal government would prove to be a powerful and unsympathetic force. The doctrinal responses to these fears crystallized into a series of constitutional provisions ${ }^{150}$ and doctrinal accretions rooted not in the text of the Constitution but in a body of decisional law. ${ }^{151}$ We are doubtful whether the fears federalism and separation of powers reflect are realistic in the context of present institutional litigation. But we shall treat them seriously because a number of critics consider them significant obstacles. ${ }^{152}$

\section{A. The Separation of Powers}

To the extent that separation of powers is a concern about institutional competency rather than about the allocation of power, we have already begun to discuss it in the preceding sections, where we suggested that these questions may be raised about classes of cases other than institutional cases. But these worries may also be viewed as part of a somewhat different inquiry, not yet pursued: whether the new litigation, regardless of its heritage, is consistent with the structure of our state and federal governments. Are courts displacing executive and legislative choices in a way that violates constitutional principles? On one level the very recitation of the question is an awkward exercise. The circumstances producing institutional litigation arise not so much because courts take action in conflict with affirmative legislative and executive programs but because courts are asked to act in a vacuum

${ }^{150}$ See U.S. ConsT. art. I (legislative power); $i d$. art. II (executive power); $i d$. art. III (judicial power).

151 See, e.g., Luther v. Borden, 48 U.S. (7 How.) I (I849); Hayburn's Case, 2 U.S. (2 Dall.) 409 (1792) (ban on advisory opinions).

${ }^{152}$ See, e.g., Nagel, supra note 2, at 68I-706 (separation of powers); Frug, supra note 2, at 743-49 (federalism); Mishkin, supra note 2, at 965-71. 
created by legislative and executive inaction or neglect. ${ }^{153}$ At another level, however, even such neglect can be characterized as an implicit choice not to allocate additional resources to the institution in question. At either level it is possible to ask whether regulating public institutions is a task so clearly and exclusively allocated to the legislative and the executive branches that judicial action is unwarranted even in the face of recalcitrance by other governmental actors.

The Constitution does not, of course, speak directly to the issue. It establishes three branches of government, but suggests little as to how or by whom the boundaries among their powers are to be drawn. Locke and Montesquieu, the expositors of modern separation doctrine who had the greatest influence on the Framers, ${ }^{154}$ offer no insight into the problem of

${ }^{153}$ See, e.g., Johnson, The Constitution and the Federal District Judge, 54 TEx. L. REV. 903 (1976). Judicial activity in school desegregation cases also may be attributable to failures by elected officials to take steps to desegregate schools. See G. ORFIELd, Must We Bus? II (1978).

${ }^{154}$ For discussions of the Locke-Montesquieu influence upon later theories of the separation of powers, see W. Gwyn, The Meaning of the Separation of Powers 66 (i965); M. Vile, Constitutionalism and the Separation of Powers 66, I2 I-22, I29-3I, I5I, I57 (but cautioning against viewing any single individual's influence on the framers as decisive) (1967); Riley, Martin Diamond's View of The Federalist, 8 Publius 7I, 76-98 (1978). See also I J. GoEbel, History of THE SUPREME CouRT OF THE UNITED STATES 28I (197 I). There seems to be disagreement as to whether modern notions of the separation principle fairly can be traced beyond Locke and Montesquieu. See Diamond, The Separation of Powers and the Mixed Regime, 8 Publius 33, 34 (1978).

Locke did not even acknowledge the judiciary as a branch of government independent of the executive. See W. GwYN, supra, at ro8; M. VILE, supra, at 59-60, 67. Montesquieu did, but viewed the judiciary primarily as a vehicle to keep the other branches in check. I C. MontesquiEU, THE SPIRIT of LAws bk. VI, chs. 56 (Colonial Press rev. ed. I900); id. bk. XI, ch. 6, I8; see W. GwYN, supra note 205, at IO8; M. VILE, supra, at $9 \mathrm{r}-96$.

Of course, this does not necessarily mean that either Locke or Montesquieu would approve of substantial accumulations of power by the judiciary. At some point surely each would disapprove of any branch of government, including the judiciary, exercising multiple governmental powers. See, e.g., I C. MontesQuiEU, supra, bk. XI, ch. 6, at I52; J. LOCKE, SECOND TREatise OF GOVERNMENT ch. XII, If 143 (Blackwell ed. 1946). But given that the American version of the separation principle allows overlap between branches of government, e.g., United States v. Nixon, 4I8 U.S. 683, 707 (I974); THE FEDERALIST No. 48 (J. Madison), we simply do not know either Locke's or Montesquieu's views on when that point is reached. Indeed, the separation principles set forth by Montesquieu, and partly inspired by Locke, see M. VILE, supra, at 79, seem to have been sufficiently flexible to allow radically different forms of government to claim fidelity to them. Id. at 78 . It is, therefore, not to be expected that Montesquieu's views would settle the details of border disputes between branches of government in a republic, a form of government he thought unsuitable for large societies, see I C. Montesquieu, supra, bk. VIII, ch. I6; M. VIle, supra, at 79; Riley, supra, at $8 \mathrm{r} \& \mathrm{n} .45,85$ (unpublished fragments of The Spirit of Laws stress importance to Montesquieu's theory that republics be small). Hamilton had to deal with this detail before claiming the fidelity of the new government to Montesquieu's views. Id. at 83-89. 
judicial excesses unresolved in the Constitution. Nor do the records of the constitutional convention or the debate surrounding consideration of the Constitution counsel specifically against judicial decisions affecting institutions traditionally regulated by executive officials. ${ }^{155}$ Although some Framers did have specific fears about the federal judiciary, ${ }^{156}$ which may raise questions concerning detailed remedies affecting public institutions, these fears are too general in nature to resolve a concrete dispute, for they imply a rejection of much of the structure of modern constitutional government.

15s The Constitution's judiciary provisions simply did not receive enough detailed attention in what has been reported of the Convention to warrant specific modern conclusions about the Framers' views on the proper limits on the judiciary. Farrand's records of the Convention contain almost no references to the separation of powers as it relates to limits on the judiciary. See 4 THE REcords of THE Federal Convention of I787, at 2 I2 (M. Farrand ed. I937) (index). But cf. I id. at r38-39 (Madison noting the desirability of separating the judiciary from the executive). Professor Goebel reports that the judiciary was subjected to much less critical analysis than the other branches of government. I J. GoEBEL, supra note I54, at 205. He surmises that the national judiciary was received "more in deference to the maxim of separation than in response to clearly formulated ideas. ... [I]f there was debate in terms of need and utility, it was not reported." Id. at 206. See generally R. Ellis, The JefFersonian CRISIS 9-16 (I97I). In the ratification struggle in Pennsylvania, debate over the separation of powers tended to focus on limits upon the executive and the legislature. See 2 The Documentary History of the Ratification of THE CONSTITUTION 775 (M. Jensen ed. I976) (index of references to separation of powers) [hereinafter cited as DocumenTARY HISTORY]. References to the separateness of the judiciary were unrelated to modern questions about specific limits on judicial power or were of a very general nature. See, e.g., 2 id. at $297,451,466,492$. For a similar trend in the ratification debates in other states, see $2 \mathrm{~J}$. Elliot, Debates In the Several State Conventions on the Adoption of the Federal CoNSTITUTION III (I836) (Holmes arguing at Massachusetts' Convention that too much judicial power remained with Congress); id. at I96-98 (Connecticut Convention); 3 id. at $55^{2}$ (Virginia Convention); 4 id. at $139-40$ (North Carolina Convention).

One possible explanation for the dearth of express discussion of limits on judicial power is the preoccupation with the question of the judiciary's relationship to legislation prior to its effectiveness - whether there should be a Council of Revision.

$[T]$ he question of what constituted powers of a judical nature was submerged into the issue of the utility and propriety of involving the judicial branch in legislation before it came before them in the form of a case or controversy. This manifested itself in the recurrent issue of a Council of Revision. The members of the Federal Convention failed to agree on the answer, and rejected such a body - which is to say that they opted for a narrower definition of judicial power in their scheme....

Diamond, The Zenith of Separation of Powers Theory: The Federal Convention of 1787, 8 PUBLIUS 45, 53-54 (r978).

156 See I J. Goebel, supra note 154 , at 280-9I; J. MAIN, The ANTIFederalists I56-57 (I96I).

Fears were expressed that federal courts would swallow up state judicial systems, see, e.g., R. Ellis, supra note 155 , at II; J. MAIN, supra, at I57; 2 DocumENTARY HrSTORY, supra note $I_{55}$, at $I_{62-63}$, that judicial power to overturn legislation was a threat to state and democratic sovereignty, see, e.g., I J. GoEBEL, supra, at 283 ; S. HaRding, The Contest Over the Ratification of the Federal ConstiTUtion IN THE STATE of MassachusetTs I9 (I896) (Elbridge Gerry suggesting 
Although constitutional structure and the reconstructed intent of the drafters are not dispositive of the limits on the judiciary, the courts themselves have interpreted at length the spirit of the Constitution's separation of powers. In article III's extension of judicial power to cases or controversies the courts have seen a series of limitations; not only the case or controversy requirement itself, but also the subsidiary doctrines of ripeness, mootness, and standing are asserted to serve the goal of separating governmental powers by preventing federal courts from performing tasks too far from the core judicial function. ${ }^{157}$ The political question doctrine similarly limits judicial intrusions upon executive and legislative prerogatives. ${ }^{158}$

Despite some commentators' efforts to use these doctrines to build a case for slowing new litigation, ${ }^{159}$ the Court's standing, ripeness, and mootness cases do not support the argument. The doctrine of standing, assertedly useful in assuring that the courts hear only those controversies in which parties with some real stake in the outcome are litigating, ${ }^{160}$ has in recent years merely required that the litigant have suffered an injury in fact caused by the harm complained of ${ }^{161}$ and that the legal interest giving rise to the complaint is protected by the Constitution or by statute. ${ }^{162}$ Similarly, notions of ripeness and mootness are designed to ensure that suits are properly timed and not brought before a controversy exists or after it has been resolved by circumstance. ${ }^{163}$ The essence of the standing, ripeness, and mootness doctrines is therefore that under certain circumstances, it is desirable to avoid judicial decisions on the merits. But the merits have long since been

national judiciary would be oppressive); J. MAIN, supra, at 157; Ellsworth, The Landholder VI (originally published on Dec. 10, 1787, in The Connecticut Courant), reprinted in EsSays on THE Constitution of THE UNITEd STATES 161, 164 (P. Ford ed. 1892) (replying to argument), and that federal judges would expand the powers of the new national government, see, e.g., J. MAIN, supra, at 156. See also Lee, Letters of a Federal Farmer, reprinted in PAMPHLETS ON THE CONSTITUTION of The UNITED States (P. Ford ed. 1888); Mason, Objections to the Proposed Federal Constitution, reprinted in id. at 327, 329-30.

${ }^{157}$ L. Tribe, AmERICan Constitutyonal Law $\$ \S 3-7$ to -17 (1978).

${ }^{158}$ See id. § 3-16.

${ }^{159} \mathrm{See}$, e.g., Frug, supra note 2, at 736-43; Nagel, supra note 2, at 706-24.

${ }^{160} \mathrm{See}$, e.g., Sierra Club v. Morton, 405 U.S. 727, 731-32 (1972).

${ }^{161}$ See, e.g., Duke Power Co. v. Carolina Environmental Study Group, Inc., 438 U.S. 59 (1978); Linda R.S. v. Richard D., 410 U.S. 614, 6I7 (1973). But see L. TRIBE, supra note $157, \S 3-18$, at 80 n.2.

${ }^{162}$ See, e.g., Association of Data Processing Serv. Organizations, Inc. v. Camp, 397 U.S. 150,153 (1970).

${ }^{163} \mathrm{See}$, e.g., International Longshoremen's Local 37 v. Boyd, 347 U.S. 222, 223-24 (I954) (ripeness); Hall v. Beals, 396 U.S. 45, 48 (1969) (mootness). 
reached in the institutional cases exercising the commentators. Those troubled by institutional cases are concerned about a quite different question: what to do once the merits have been determined adversely to the government. Cases that terminate prior to the merits, and the interests most directly served by those cases, are simply not on point.

An attempt has also been made to suggest limits on the new litigation by resort to the political question doctrine. ${ }^{164}$ A fundamental but unfocused version of this argument suggests that each time a court orders an institutional remedy, even if it does not overstep a well-defined legal line separating the judiciary from the other branches of government, it concentrates power in one branch, thereby weakening the constitutional system of checks and balances. In response, it might be contended that the separation of powers is less an idea than an institutional condition, a condition that survives the new litigation. Judges still must await the filing of a case and still remain limited to resolving the disputes before them. Another version of the argument asserts that important values served by the political question doctrine would be served by limiting the new litigation. ${ }^{165}$ To the extent the doctrine tests "whether the Constitution has committed to another agency of government . . . autonomous determination of the issue raised," 166 however, it bears little relation to most issues raised in institutional litigation. For while this doctrine might be violated by adjudication of some issues, such as the proper forms of state government, or presidential conduct of foreign policy, ${ }^{167}$ no constitutional provision requires that executive and legislative officials be the sole or final judges of institutional conditions.

To some, however, the political question doctrine involves a more subtle inquiry: not whether the Constitution expressly leaves decisions to other branches of government but whether courts are able "to derive enforceable rights from the constitutional provisions ... the litigants invoke." 168 A recent case simultaneously illustrates such concerns and indicates why they do not speak directly to the circumstances of most institutional litigation. In Gilligan v. Morgan, ${ }^{169}$ the Supreme Court re-

${ }^{164}$ See, e.g., Frug, supra note 2, at 749-50.

165 See id.

${ }^{166}$ Wechsler, Toward Neutral Principles of Constitutional Law, 73 HARV. L. REV. I, 7-8 (1959). (1948).

${ }^{167}$ See, e.g., Chicago \& S. Air Lines v. Waterman S.S. Corp., 333 U.S. 103

${ }^{168} \mathrm{~L}$. TRIBE, supra note $157, \S 3-16$, at 76 . For a more complete survey of the various views of the political question doctrine, see id. $\S 3-16$, at $7 \mathrm{I}$ n.r.

${ }^{169} 4$ I3 U.S. I (I973). 
fused to permit an action against the Ohio National Guard that sought to shape the atmosphere of the Guard's operations and training program to ensure that the Guard did not use excessive force in the future. The suit had been prompted by the allegedly excessive force used in suppressing demonstrations at Kent State University. In dismissing the case, the Court suggested that its decision was influenced by limits on the judicial capacity to administer the relief requested. Framing a remedy for the alleged violations would, the Court indicated, "require a judicial evaluation of a wide range of possibly dissimilar procedures and policies approved by different law enforcement agencies or other authorities . . . . It would be inappropriate for a district judge to undertake this responsibility [even] in the unlikely event that he possessed [the] requisite technical competence to do so." 170 The words sound applicable to institutional cases. If courts cannot oversee the training of the Guard, how can they hope to oversee the administration of prisons and mental hospitals?

Yet institutional cases should not be expected to generate similar holdings. It is doubtful that the "real" basis for Gilligan was a fear of the difficulty of framing a remedy. Gilligan at bottom involved an effort to prevent future Guard misbehavior by having courts dictate Guard practices. There were no allegations of continuing unconstitutional behavior by the Ohio Guard. ${ }^{171}$ A concurrence by Justices Blackmun and Powell, whose votes were necessary for a majority holding, highlighted the speculative nature of the Gilligan case. The complaint was based on a single past incident and contained "allegations of unspecified, speculative threats of uncertain harm that might occur at some indefinite time in the future." 172 They indicated that different issues would be raised by relief sought in a nonspeculative factual setting. ${ }^{173}$ Institutional cases, all too starkly, present factual settings involving what no one could reasonably term speculative threats of uncertain harm.

Finally, it is important to note that standing and timing issues are influenced by, respectively, the nature of the harm alleged and the merits of the case. ${ }^{174}$ Courts deny access for lack of standing when no one demonstrates a direct, tangible harm that justifies cranking up the federal judicial machin-

170 Id. at 8.

171 Id. at 5 .

${ }^{172} \mathrm{Id}$. at $\mathrm{I}^{-14}$ (Blackmun, J., concurring).

${ }^{173} I d$. at I4. Four Justices believed the case to be moot. Id. at 12 (Douglas, Brennan, Stewart \& Marshall, dissenting).

${ }^{174}$ See, e.g., A. Bickel, The Least Dangerous Branch r69-70 (1962). 
ery. The invocation of such doctrines in institutional litigation, where the harms are all too tangible and direct, is inappropriate. A similar point can be made with regard to the political question doctrine: if Tennessee's rotten boroughs had been a bit less rotten, Baker $v$. Carr, ${ }^{175}$ the cornerstone of modern political question theory, would not have pushed the Court so strongly toward redistricting. Thus one writer has asked whether the same result would have been forthcoming in Gilligan if the state "had been sending homicidal maniacs into the streets with loaded guns and instructions to do what was needed to keep order." 176 As hyperbolic as it is, the hypothetical case is a closer analogue to the institutional cases than are the facts of Gilligan. Those who concede the existence of constitutional violations in institutional cases - and few of the writers under scrutiny here have cared to question this aspect of the cases - are hard-pressed to justify using such doctrines of restraint to limit judicial action.

\section{B. Federalism}

Questions of federal-state relations arise when a federal court makes intrusive orders regulating state institutions. The constitutional validity of such orders is determined in this context by reference to principles of federalism. In post-civil war America, particularly in the absence of contrary congressional instructions, one may start with the premise that unconstitutional behavior by state or local officials may be remedied by federal suits for equitable relief. ${ }^{177}$ In recent years, however, the exceptions to this premise have made substantial inroads into its scope. The rationales of recent federalism cases such as National League of Cities v. Usery, ${ }^{178}$ Younger v. Harris, ${ }^{179}$ and Rizzo v. Goode ${ }^{180}$ are sufficiently open-ended to suggest arguments questioning the validity of the federal judiciary's ventures into state affairs. ${ }^{181}$ Yet, in important respects, these recent federalism cases are distinguishable from most institutional cases.

In National League of Cities (NLC) the Court held unconstitutional Congress' effort to extend minimum wage and max-

175369 U.S. I86 (1962).

176 D. CURRIE, FEDERAL COURTS I3I (2d ed. I975).

177 See, e.g., Mitchum v. Foster, 407 U.S. 225 (1972); Ex parte Young, 209 U.S. I23 (1908). See also Monroe v. Pape, 365 U.S. 167 (I96r) (damage action).

178426 U.S. 833 (I976).

179401 U.S. 37 (1971).

180423 U.S. 362 (1976).

181 See, e.g., Nagel, supra note 2, at 717-I8; Fiss, Dombrowski, 86 YALE L.J. II03, II48-60 (I977). 
imum hour provisions of the Fair Labor Standards Act $(\mathrm{FLSA})^{182}$ to state and local government employees. In so doing the Court indicated that states retain "freedom to structure integral operations in areas of traditional governmental functions." 183 The Court emphasized the budgetary effects of a minimum wage requirement and noted that compelled compliance with federal standards would deprive the states of power to choose the manner of delivering necessary government services. ${ }^{184}$

Implications for institutional litigation are readily derivable from $N L C$. The government activities involved in most institutional cases relate to subjects, such as health and welfare, that, like the setting of wages of government employees, are within the state's traditional powers. ${ }^{185}$ Federal orders that substantially affect the manner in which those powers are exercised are intrusive, whether the orders come from Congress or the federal courts. Similarly, if the cost of compliance with the FLSA is worthy of consideration in striking the federalstate balance, why is not the cost of compliance with remedial orders in institutional cases?

There are, however, two major problems with applying $N L C$ to institutional cases. First, such an application would prove too much. Any time a federal court orders state officials to do anything there are likely to be both monetary implications and restrictions on how the state may exercise its traditional authority. Extensions of NLC along the lines noted above would deprive Congress and the federal courts of power to redress most constitutional deprivations by state officials. Such extensions of federalism's limitations would entail a dramatic redefinition of the relationship between federal courts and the states. Second, the facts of institutional cases uniformly reveal a circumstance not present in $N L C$ - unconstitutional behavior by state or local officials. NLC might well have been decided differently if the congressional action had been taken to remedy unconstitutional behavior by state officials rather than to impose upon localities standards not required by the Constitution. ${ }^{186}$ Whatever doubts there may be

182 Pub. L. No. 93-259, § 6(a)(I), (5), (6), 88 Stat. 58 (I974) (codified at 29 U.S.C. $\S 203(\mathrm{~d}),(\mathrm{s}),(\mathrm{x})(\mathrm{I} 970))$.

${ }^{183} 426$ U.S. at 852.

${ }^{184}$ Id. at $846-48$.

${ }^{185}$ See, e.g., Preiser v. Rodriguez, 4II U.S. 475, 491-92 (x973).

${ }^{186}$ See 426 U.S. at 852 n.I 7 ; $c f$. North Carolina ex rel. Morrow v. Califano, 435 U.S. 962 (r978), aff'g 445 F. Supp. 532 (E.D.N.C. 1977) (summary affirmance of district court holding that Congress could condition federal aid on state's compliance with federal standards). 
about Congress' power to impose standards upon states and localities in areas of traditional government, there is far less doubt that Congress has the power to authorize federal lawsuits to redress unconstitutional behavior by those entities even to the point of abrogating the states' sovereign immunity. ${ }^{187} N L C$ is thus of little direct relevance to institutional litigation.

The critical element missing from the state conduct sought to be regulated in $N L C$, behavior in violation of the fourteenth amendment, was, however, involved in a second pillar of contemporary federalism, Younger v. Harris. ${ }^{188}$ In Younger, a Californian indicted under the state Criminal Syndicalism Act filed a complaint in federal district court seeking an injunction against the prosecution on the ground that it deprived him of first and fourteenth amendment rights. In explaining its refusal to grant injunctive relief, the Court relied upon the triad of equity, comity, and federalism. Equity doctrines, it ruled, precluded injunctive relief because "courts of equity should not act, and particularly should not act to restrain a criminal prosecution, when the moving party has an adequate remedy at law and will not suffer irreparable injury if denied equitable relief." 189 Principles of federalism required a proper respect for state functions in a system in which the federal government, while protecting federal rights, does so "in ways that will not unduly interfere with the legitimate activities of the States." 190 Because Younger cases are always characterized by allegations of unconstitutional behavior by state officials, one may ask whether Younger imposes limits on institutional cases.

But the rationale of Younger leaves institutional cases untouched. One can concede that federal courts should not interfere with pending state proceedings without affecting the results in institutional cases. Under Younger, federal actions contemporaneous with pending or threatened state proceedings are considered to interfere to a much greater degree with state functions, particularly state judicial functions, than are federal suits in the absence of such proceedings. Such pending state proceedings rarely accompany institutional cases. Because an extension of Younger to cases in which no state proceeding is pending would have extremely broad implications for federalstate relations, such an extension should be by express mandate

\footnotetext{
${ }^{187}$ See, e.g., Hutto v. Finney, 437 U.S. 678 (1978); Milliken v. Bradley, 433 U.S. 267 (1977).

18840 I U.S. 37 (r97x).

${ }^{189} \mathrm{Id}$. at $43-44$.

190 Id. at 44 .
} 
of the Court and not by lower courts guessing that such a result is the one demanded by Younger.

Yet there is language in a third pillar of modern federalism, Rizzo v. Goode, ${ }^{191}$ which could be read to support such an extension. In Rizzo, plaintiffs in two class actions sought federal equitable relief from an allegedly pervasive pattern of unconstitutional action by Philadelphia police officers. The district court, after hearing evidence concerning forty incidents of alleged police misbehavior, granted equitable relief consisting of a detailed program, negotiated between plaintiffs and city officials, governing the way in which citizens' complaints against the police department would be handled by the department. ${ }^{192}$

The Supreme Court, however, using language with potential implications for institutional litigation, discarded the program. To the majority it represented an "unwarranted intrusion by the federal judiciary into the discretionary authority committed to [the defendants] by state and local law to perform their official functions." 193 This conclusion was based in part upon concerns for federalism although no state court litigation was pending. The Court announced that principles of federalism apply where relief is sought from the conduct of state or local executive officials as well as from state judicial proceedings. ${ }^{194}$ Thus Rizzo combines two factors which were present in isolation in $N L C$ and Younger: an allegation that state officers were acting unconstitutionally and an application of federalism to deny relief where no related state litigation was in progress.

Yet even this retreat of federal judicial power provides scant support for a major shift in the pattern of institutional litigation. First, the Court in Rizzo was in large part concerned with the question whether an Article III case or controversy existed. ${ }^{195}$ The Court was troubled by the lack of connection between those officials sued, those against whom the injunction would operate, and those who performed the actual misdeeds. ${ }^{196}$ Second, and more importantly, the Court found that the facts failed to demonstrate the pervasive pattern of police violations found necessary in other cases to enjoin a

191423 U.S. 362 (ז976).

192 Id. at 365 n.2.

$193 \mathrm{Id}$. at 366.

194 Id. at 379-80.

195 Id. at $37 \mathrm{I}-72$. But see Fiss, supra note $\mathrm{I} 8 \mathrm{I}$, at $1154-58$ (questioning article III analysis in Rizzo).

196 Id. at 37 I (quoting Rizzo v. Goode, 506 F.2d 54I, 548 (3d Cir. 1974)) (emphasis in original). 
police department. ${ }^{197}$ Seen in this light, Rizzo's facts distinguish it from the mainstream of institutional litigation. ${ }^{198}$ In such litigation there is little doubt that those suing, generally a relatively small and homogenous group, are suffering direct, tangible, and pervasive harm at the hands of those being sued and that most state institutions against whom relief is granted are entangled in a pervasive pattern of constitutional violations found wanting in Rizzo. ${ }^{199}$

Rizzo and the recent cases on federalism, like the cases on separation of powers, reveal sensitivity to and are influenced by the strength of the case on the merits. In $N L C$, the case for federal intervention is weakest because neither states nor units of local government are acting in violation of the Constitution. The relatively tenuous connection between the violations and the defendants in Rizzo stands in sharp contrast to the direct relationships that often exist between the suffering of an inmate population and those who control institutions. Even the Younger doctrine is expressly sensitive to the merits of the underlying claim for injunction. ${ }^{200}$

${ }_{197} 423$ U.S. at $373-77$. See also Comment, supra note I, at 383 (suggesting holding in Rizzo turned on lack of constitutional violation).

${ }^{198}$ See, e.g., Campbell v. McGruder, 580 F.2d 521, 536-40 (D.C. Cir. 1978); authorities cited in Goldstein, supra note I, at I8 n.87.

O'Shea v. Littleton, 4r4 U.S. 488 (1974), has also been relied upon to support limiting institutional litigation. See Frug, supra note 2, at 746-48. Yet $O$ 'Shea seems materially distinguishable from the mainstream of institutional litigation. In $O$ 'Shea, plaintiffs alleged that state and local officials were administering the criminal justice system in a discriminatory manner. 4I4 U.S. at 490-92. Initially, the Court held that there was no case or controversy between plaintiffs and defendants. "None of the named plaintiffs is identified as himself having suffered any injury in the manner specified." Id. at 495. The Court went on to state that even if there were a case or controversy, a sound basis for equitable relief had not been established. In finding this basis lacking, the Court emphasized that plaintiffs sought "an injunction aimed at controlling or preventing the occurrence of specific events that might take place in the course of future state criminal trials," id. at 500, a circumstance which brought O'Shea perilously close to the Younger rationale and one which distinguishes O'Shea from most institutional litigation, where related state judicial proceedings are not implicated. The Court's statement of the "objection" to relief in O'Shea seems inapplicable outside the context of possible related state judicial proceedings. "The objection is to unwarranted anticipatory interference in the state criminal process by means of continuous or piecemeal interruptions of the state proceedings by litigation in the federal courts...." Id.

199 Alternatively, one might argue that the underpinnings of Rizzo are too hazy to warrant its employment as a precedent for prediction of future cases, see $\mathrm{L}$. TRIBE, supra note $157, \S 3-4 \mathrm{r}$, at $154-56$, or that Rizzo simply was wrongly decided, see Chayes, supra note I, at 1304-07; Fiss, supra note $18 \mathrm{I}$, at I154-55 n.172. See also Mishkin, supra note 2, at 975; Shapiro, Mr. Justice Rehnquist: A Preliminary View, 90 HARV. L. REV. 293, 318-20 (r976).

${ }^{200} \mathrm{See} 40 \mathrm{I}$ U.S. at 46. 
All of this is not meant to deny that respect for state and local institutions is relevant in institutional litigation. Despite broad remedial decrees, institutional cases can evidence such respect in ways short of allowing constitutional violations to go unremedied. In many institutional cases, the deliberate pace of the litigation, the substantial guidance sought and obtained from state executive defendants in framing relief, and decrees that are cleared in advance with defendants, manifest deference to the states and their officials. The real question is not whether states are shown respect, for they are, but whether their status is such that they are entitled to the final word about the nature of institutional conditions and the pace at which those conditions are brought into compliance with the Constitution. Since Cohens v. Virginia, ${ }^{201}$ the answer to this question has been no.

\section{Institutional Litigation and the Public Fisc}

While the limits required by the principles of federalism and separation of powers reflect conflicts between the courts and executive prerogatives, in at least one important respect institutional litigation has been asserted to intrude upon a quintessentially legislative choice, the allocation of social resources. The existence of judicial authority to allocate funds raises particular concern in the new litigation because some of what courts order is costly. ${ }^{202}$ Some courts disavow authority to force defendants in institutional cases to raise funds. ${ }^{203}$ Other courts refuse to accept lack of funds as an excuse for noncompliance with constitutional standards ${ }^{204}$ and therefore may be implicitly ordering allocation of public funds. ${ }^{205}$

201 Ig U.S. (6 Wheat.) 264 (182 I).

202 See, e.g., Milliken v. Bradley, 433 U.S. 267, 293 (1977) (Powell, J., concurring); Williams v. Edwards, 547 F.2d I206, I2 18 (5th Cir. 1977); AlabaMa Civil Liberties Union foundation National Prison Project, The Alabama Prison System (1977); Frug, supra note 2, at 727-30.

${ }^{203}$ Jones v. Wittenberg, 323 F. Supp. 93 (N.D. Ohio); 330 F. Supp. 707, 712 (N.D. Ohio I97r), aff'd sub nom. Jones v. Metzger, 456 F.2d 854 (6th Cir. 1972); Hamilton v. Love, 328 F. Supp. II82, II94 (E.D. Ark. I97r). But see Griffin v. County School Bd., 377 U.S. 218, 233 (1963); Virginia v. West Virginia, 246 U.S. 565 (I918); Reed v. Rhodes, 455 F. Supp. 569, 606 (N.D. Ohio I978); Evans v. Buchanan, 447 F. Supp. 982, 1026-35 (D. Del.), aff'd, 582 F.2d 750 (3d Cir. 1978) (en banc).

${ }^{204}$ See, e.g., Finney v. Arkansas Bd. of Correction, 505 F.2d 194, 20I (8th Cir. 1974); Lora v. Board of Educ., 456 F. Supp. I211, 1292-93 (E.D.N.Y. 1978); Vest v. Lubbock County Comm'rs Court, 444 F. Supp. 824, 834 (N.D. Tex. 1977); authorities cited in Frug, supra note 2, at 725-26 \& nn.7 I-72.

${ }^{205}$ Whether such courts are in fact allocating funds may depend upon one's view of the viability of ordering an offending institution closed. If an order to close is an unrealistic alternative, see Frug, supra note 2, at 728-29, then refusing to excuse noncompliance for lack of funds may, depending upon compliance with the remedial 
The conclusions derived from this concern may take either a strong or a weak form. On the one hand, it may be simply argued that in framing relief for constitutional violations, federal courts ought to be at least cognizant of budgetary considerations. Courts should pause before ordering costly relief, should do so only to the extent necessary to remedy violations, should seek counsel about costs from those responsible for implementing the decree, and when possible should avoid direct confrontations with authorities over money matters. ${ }^{206}$ In short, the deference due on fiscal issues is similar to that due officials in general. On the other hand, this call for judicial deference to legislative control of the purse may be taken not merely as a monitory counsel but as an absolute barrier to certain remedies. Such barriers are a possible result if, as has been argued, remedies in institutional litigation are constitutionally limited by the notion that the amount of money to be made available is solely a legislative choice; ${ }^{207}$ the orders courts make in institutional cases will, almost inevitably, have as their consequence the increased expenditure of public funds. This fact cannot serve to invalidate institutional litigation, however, because it proves too much. For a judicial order in almost any case has either as its aim or as its consequence the reallocation of resources. That is what litigation is for.

When the courts order the government to observe an individual's right, the government must relinquish some existing claim of dominion over that individual. This diminished authority may obscure a corresponding and inevitable financial expense: whatever money the individual might have provided must be raised in some other way, or the government's desired objective must be attained through the exertion of extra effort on its part. When, however, the person asserting the newly recognized right is particularly dependent on the government, recognition of the right may involve a more obvious, direct expenditure of funds: a schoolchild must be given certain educational advantages, a prisoner must receive an additional blanket, an inmate of a mental institution must be furnished with medical care. But whether or not the expenditure is obvious, judicial enforcement of individual rights often necessarily involves the reallocation of funds.

decree, in effect allocate public resources. A number of courts, however, have ordered institutions closed. See, e.g., Inmates of the Henry County Jail v. Parham, 430 F. Supp. 304 (N.D. Ga. 1976); authorities cited in Goldstein, supra note I. See generally note 2 I 9 infra.

206 Frug, supra note 2, at $773-84$.

207 See id. at 788; Mishkin supra note 2 , at 970-7 7. Heinonl ne $_{3} 507$ 1979-1980 
Thus, when the Supreme Court in Goldberg v. Kelly 208 held that welfare dispensers had to give recipients a hearing before ending their benefits, it implicitly decided that additional funds would have to be expended for this purpose hearing officers must be paid. Again, the Court noted explicitly that the added administrative burdens would necessitate further expenditures. ${ }^{209}$ Moreover, when the Court held in Gideon v. Wainwright ${ }^{210}$ that an indigent criminal defendant's constitutional right to counsel requires the government to provide a lawyer, it indicated directly that both state and federal governments would have to spend more money to fulfill this obligation. ${ }^{211}$

As a final example, the Court's decision in Griffin v. School Board $^{212}$ contains an explicit recognition that courts may order that funds be raised and expended to enforce substantive rights. The Court, reacting to defiance of desegregation decrees, made it clear that the district court could order new taxes levied to pay for a desegregated school system. That the Court was reacting to intransigence would not seem to deprive Griffin of its relevance as a precedent for institutional cases. As noted earlier, at least some of the detail and intrusiveness of the decrees in institutional cases derives from litigant intransigence. In one respect, moreover, other institutional cases levy an even more compelling demand on the fisc than desegregation cases. In at least some institutional cases, ${ }^{213}$ prompt change has been found necessary to protect health and lives from clear and present dangers. ${ }^{214}$

Because there are relatively few cases directly on point, there is little guidance as to the circumstances under which the Court would approve resort to such a remedy. It is conceivable that the Court might decline to extend the remedy to new factual situations. At this point in the Court's fiscal jurisprudence, however, no insuperable doctrinal barrier precludes con-

208397 U.S. 254 (I970).

209 Id. at 266.

210372 U.S. 335 ( 1963$)$.

$211 \mathrm{Id}$. at 344 .

212377 U.S. 218, 233 (1964).

${ }^{213}$ See, e.g., Williams v. Edwards, 547 F.2d 1206 (5th Cir. 1977); Battle v. Anderson, 376 F. Supp. 402 (E.D. Okla. I974), aff'd, 564 F.2d 388 (Ioth Cir. 1977); Gates v. Collier, 349 F. Supp. 881 (N.D. Miss. 1972), aff'd, 501 F.2d 1291 (5th Cir. I974); Holt v. Sarver, 300 F. Supp. 825 (E.D. Ark. 1969); 309 F. Supp. 362 (E.D. Ark. 1970), aff'd, 442 F.2d 304 (8th Cir. r97I).

${ }^{214}$ See, e.g., Wyatt v. Stickney, 325 F. Supp. 78I (M.D. Ala.), hearing on standards ordered, 334 F. Supp. I34I (M.D. Ala. I97 I), enforced, 344 F. Supp. 373 (M.D. Ala.); 344 F. Supp. 387 (M.D. Ala. 1972), aff'd sub nom. Wyatt v. Aderholt, 503 F.2d I305 (5th Cir. 1974). 
sideration of stern fundraising measures by lower courts. Under existing precedent, refusal to implement a decree for lack of available funds is not an acceptable excuse for noncompliance.

Even if precedent spoke less equivocally than it does, there would be room to argue about the policies that lie behind fiscal criticisms of the new litigation. Questions of the purse are at bottom questions about the allocation of public resources. Uneasiness about the courts' requiring other governmental agencies to allocate funds stems in part from the belief that courts are not good at ranking priorities and choosing the means to meet the goals once the ranking is done. ${ }^{215}$ Yet in its purest form such a belief would preclude any public law litigation, for all such adjudication necessarily involves ranking certain social goals above others. For example, in Griffin $v$. Illinois, ${ }^{216}$ the Court held that if Illinois operated a system of criminal appeals in which transcripts were available to some appellants, it had to provide free transcripts to appellants unable to afford them. If one characterizes the goal of Griffin as that of achieving a fair criminal justice system, the decision is objectionable on the grounds that the goal might have been better served by spending the same funds to hire more or better defense lawyers or investigators, thereby improving the quality of trials and obviating appeals; at least one could argue that the legislature, traditionally in control of funds, could rationally have so decided. The difficulty with this argument is that, stated in such broad terms, it precludes all judicial decisions with fiscal effect. The allocative problem disappears, however, as soon as one is willing to say that the claimant has an entitlement by virtue of the substantive law. And just such decisions about entitlement lie at the heart of public adjudication; even the advocates of fiscal restraint do not go so far as to argue that cases like Griffin constitute unwarranted judicial meddling in allocative decisions. ${ }^{217}$

At this point the foe of judicial allocative meddling has a problem. On one hand he is pressed by his conviction that free-floating judicial allocation is an evil. Yet once he concedes the legitimacy of cases like Griffin he may be hard put to define a stopping point. We think that searching for such a point yields a useful insight into modern institutional litigation,

${ }^{215}$ See, e.g., Frug, supra note 2, at 788; Mishkin, supra note 2, at 965; Schoettle, The Equal Protection Clause in Public Education, 71 CoLUM. L. REv. I355, 1393418 (I97I).

${ }^{216} 35$ I U.S. I2 (1956).

${ }^{217}$ See, e.g., Frug, supra note 2, at 76I (Griffin not as intrusive as institutional cases). 
one that suggests that agreement upon any single stopping point is most unlikely. For the strength of the objection that courts are making essentially arbitrary allocative decisions seems to vary according to the type of institutional case under consideration. Critics of institutional litigation might therefore see more clearly if they ceased to treat all institutional cases as a single category and concentrated instead on the substantive rights implicated in each individual case.

\section{Property and People}

Finally, focusing on the merits of each individual case, we do perceive much about the new litigation that is new. We differ from many of the commentators only in asserting that the novelty lies less in the procedural or remedial aspects of the cases than in the rights they protect, the direction in which they redistribute power. For centuries courts have been invoking the remedies they employ in institutional cases, but they have been invoking them to vindicate a long established set of rights that has become the social institution we call property. Courts are now invoking such remedies in aid of new rights of individuals and groups. To focus on the remedial phases of the new litigation is therefore misleading, for there has not been a shift in the remedies which courts are willing to invoke so much as a shift in the rights in whose aid they are willing to invoke these remedies.

The shift has been occurring over the last few decades, as courts have created a series of new constitutional rights redounding to the benefit of such unprepossessing groups as criminal defendants. ${ }^{218}$ As long as these new rights could be asserted in such classical forms as the constitutional challenge to a criminal conviction, the need for expansive remedial decrees did not exist. ${ }^{219}$ But not all new rights had such a purely defensive significance. In particular, civil rights litigation has

218 See, e.g., Gideon v. Wainwright, 372 U.S. 335 (1963); Mapp v. Ohio, 367 U.S. 643 (196r).

219 This is not to say that such cases did not as a practical matter call forth significant institutional changes; one need only recall the public defender system that had to be created or enlarged in the wake of Gideon v. Wainwright, 372 U.S. 335 (I963). What such cases as Gideon and Miranda v. Arizona, 384 U.S. 436 (1964), did not do was to put any particular institution under continuing judicial supervision; instead the Supreme Court told police, prosecutors, and court systems that if they wished to secure convictions that would survive appeal, such convictions had to be the products of a law enforcement system with certain features. The choice of system was left to the various jurisdictions involved. From one perspective the apparently more intrusive orders typical of the institutional cases are a product of judges' and parties' unwillingness to put the institutions involved to such a drastic choice. Courts, 
spawned many new classes of rights that cannot be protected by acquittal or reversal of a conviction. To enforce these new rights the courts have borrowed from a remedial arsenal first fitted out to vindicate interests of a rather different sort. ${ }^{220}$ In the new litigation, then, old remedies are implementing new rights.

These new affirmative rights are a product of recent social history. An incontrovertible feature of modern American life is our growing involvement in continuous relationships with large public and private institutions. As Charles Reich has noted, new forms of property are increasingly found in the expectation of largesse from government on some continuing basis. ${ }^{21}$ Thus some umpiring of people's relationships with institutions is inevitable, and the new institutional litigation is merely one product of these new relationships.

Yet institutional litigation has some special characteristics that may affect one's evaluation of it. Unlike the claimants Reich discusses in The New Property, ${ }^{222}$ the litigant in institutional cases is not seeking to improve his situation vis-à-vis the institution from a position of what might be called voluntary neutrality; rather, he is compelled to be attached to the institution for some period of time. Even the welfare claimant who asserts entitlement to some benefit is not simultaneously deprived of subsistence and compelled by the welfare system to depend on it for his sole means of support;223 yet such is

instead of ordering changes in Alabama's prisons, could simply order the release of all the inmates until such time as certain conditions had been met.

Such a course of action would be even more unpopular than the road taken by most institutional cases; but it would meet many of the objections of the commentators on the new litigation, for it would involve courts neither in the day-to-day supervision of institutions, requiring that they reenter the dispute only to decide if the defendant had complied, nor in the intrusions into state, legislative, and executive functions that the constitutionalist commentators worry about. Thus one way of looking at the more detailed involvement of the courts in the lives of institutions is to see it as a product not of judicial muscle-flexing but of a withdrawal from the more dramatic either/or holdings typical of the constitutional criminal rights cases.

220

In fashioning and effectuating the [desegregation] decrees, the courts will be guided by equitable principles. Traditionally, equity has been characterized by a practical flexibility in shaping its remedies and by a facility for adjusting and reconciling public and private needs. These cases call for the exercise of these traditional attributes of equity power.

Brown v. Board of Educ., 349 U.S. 294, 300 (1955) (citations omitted).

${ }^{221}$ See Reich, The New Property, 73 YALE L.J. 733 (1964).

222 Reich considered the entitlements of persons receiving what he terms largesse from the state in the forms of income, jobs, occupational licenses, franchises, contracts, subsidies, and permission to use public resources. Id. at 734-36.

223 The Supreme Court has put this fact to rather bizarre use in Wyman v. James, 400 U.S. 309 ( $197 \mathrm{I})$, in which it held that the noncompulsory nature of welfare meant 
the condition of the prisoner, the inmate, and, though in a far less comprehensive way, the schoolchild. Courts therefore do not have the option of simply severing the relationship between the plaintiffs and the institutional defendants. They must instead implement continuous, complex remedies to deal with unresponsive defendants if they are not to abdicate judicial responsibility in the face of the abrogation of constitutional rights.

Despite the novelty of these relationships, however, such rights have ancient analogues: they are the latest products of a social development that produced our most venerable common law writs. The developments we are now witnessing in institutional cases are part of a continuing rearrangement of power within a larger social structure. These processes arose with the beginning of Anglo-American legal culture; the oldest, now most familiar rights grew out of a similar series of clashes that seem rather familiar to the observer of institutional litigation. In medieval England, both vassal and villein acquired rights as the powers and discretion of their superiors, be they feudal lords or manorial proprietors, were increasingly limited. Along the way the inferior acquired first status and then property; a similar process appears to be at work in the institutional cases although the details differ. ${ }^{224}$

This larger context is in part obscured by a factor that exacerbates the tendency to see parts of the new litigation as completely novel: the absence of mature subjudicial institutions to handle the supervisory aspects of enforcing a decree. Throughout this essay, in describing legal organizations that perform functions analogous to those of courts in the new, public litigation, we have noted that the analogies are not immediately apparent because the organization in question has been "spun off" from the judiciary, or at least from our core idea of "adjudication." One need only think of trustees (regular and bankruptcy), specialized procedures (examination of debtors for assets) and officers (sheriffs, special masters, re-

that the dispensing jurisdiction could constitutionally require a recipient to choose between submitting to a warrantless inspection of her home by welfare authorities and termination of her benefits. But cf. Goldberg v. Kelly, 397 U.S. 254 (1970) (holding that a recipient of welfare is entitled to an administrative hearing before aid is terminated).

${ }^{224}$ For the evolution of the rights of vassals, see I M. BLOCH, Feudal Society I97 (I96I); N. Cantor, The ENglish 87-91 (I967); S. Milsom, The Legal FrameWORK OF ENGLISH FEUDALISM 8-35 (1976). For the evolution of the rights of villein tenants, see N. CANToR, supra, at I2-I6; C. GRAY, Copyhold, EQUiTy, AND THE COMmon LAW 12-i6 (1963); A. Simpson, AN Introduction to the History of the Land LaW 150-5i (196r). See also R. Tawney, The Agrarian Problem in the SiXteenth Century 40-45 (L. Stone ed. I967). 
ceivers), and, in at least one notable instance (bankruptcy), entire specialized institutions, to realize that the new litigation seems new because we are seeing what in other areas of the law have become separate, mature apparatuses for handling the sorts of problems that courts have to deal with on a homemade basis in the "new" litigation. Because we have little familiarity with the progress made by such systems in their infancies, ${ }^{225}$ it is easy for us to forget that they frequently were awkward and stumbling at that stage of their lives. To compare them in their mature sophistication to the early stages of institutional litigation is therefore inappropriate.

The comparison is also deceptive, for it exaggerates the amount of uncertainty and strife about doctrine that can be expected in a mature litigious system. ${ }^{226}$ Some of what courts do today in administering new remedies may, should the substantive rights in question survive and flourish, come to be viewed as misguided or worse. Moreover, the substantive rights that do survive to adulthood tend to accrete rules about usual and extraordinary remedies, and as these rules develop two corollary effects occur. First, courts come to have, in many cases, relatively little difficulty in deciding upon a remedy; second, as defendant institutions become accustomed to it, there is less controversy over the remedy and more over the occurrence of the facts that trigger its imposition. There may come a time when there is a Court of Institutional Receivership to which the supervision of wayward agencies is committed. If such a thing ever happens, one imagines that the litigation will focus not on whether the court is an abomination and an outrage but on whether the institution in question has violated the Constitution.

The case for such specialized subcourts is far from clear. It is not obvious, for instance, that the issues involved in bankruptcy are so patently different from those in other adjudications that a separate institution is needed. One might just as well view courts' functions in other cases as being essentially different and call for Courts of Contracts, Torts, Civil \& Constitutional Rights, Antitrust, and Environmental Law to join the Court of Claims, the Tax Court, and the like;

\footnotetext{
225 It is perhaps more exact to assert that we have experience with such institutions, but not in judicial form; in the past several decades the task of such institutional spadework has frequently been given to administrative agencies, possessed of what the Progressives liked to call expertise - a term that often denoted no more than willingness to try to do something about a situation.

${ }^{226}$ One need only recall that the Interstate Commerce Commission in its early years was the object of intense debate. See R. Wiebe, The SEARCH For ORDER I877-1920, at 53 (1967).
} 
indeed some such arguments are from time to time advanced. ${ }^{227}$ Such proposals seem to us to ignore the five hundred years of experience with just such specialized courts and the forces that led to the gradual consolidation under one judicial roof of the jurisdictional specialties of such quaint tribunals as the Courts of Request, the Dutchy and finally, in most systems, even Chancery itself.

Whatever their merits, however, such proposals have in common with the suggestion that specialized courts be abolished and their duties assigned to "normal" courts the recognition that there is no essentially judicial enterprise, that courts are administrative arms of the state that take now one and now another form as convenience and political expediency dictate. Society can and will fight over the allocation of power among individuals and social groups that such shifts entail, but let us be candid enough to admit that it is that allocation of power rather than some institutional essence with which we are concerned.

This recognition illuminates much of the controversy over the new litigation and also suggests its limits. The reason some perceive a difference in the degree of judicial intrusion in institutional cases is, quite simply, because perceptions of the merits differ. It is easy to imagine widespread attack on a judicial decree ordering, in the name of equality, one method of reading instruction rather than another: one simply cannot, the argument would go, rely on the courts for managerial decisions that the school board and teachers should make on the basis of substantive expertise. In prison or hospital litigation it would be more difficult to find a comparable example of judicial meddling. Beatings and starvation do not receive good press, and orders that they cease, when not complicated by litigant intransigence, do not appear to involve much judicial managing. There is likely to be more uniformity of view on the question whether some aspect of institutional life is indecent, and what steps might ameliorate the situation, than there is on what constitutes educational inequality and what will eliminate it. Many might draw a line at a decree requiring inmates to have showers with a particular soap; accordingly, such a decree would seem largely arbitrary and therefore entitled to no more weight than the judgments of administrators.

We have not chosen our example from an imagined school inequality case purely by chance, for it is in such litigation

${ }^{227}$ E.g., U.S. Appeals Plan: Success at Last?, NAT'L L.J., Sept. 25, 1978, at I, col. I (reporting the Justice Department's proposal to "merge the Court of Claims and the Court of Customs and Patent Appeals and [have the new court] take on nationwide jurisdiction of patent, civil tax and environmental appeals"). 
that courts are most frequently criticized for ordering essentially arbitrary changes for marginal gains at best. Once it is agreed that state-ordered segregation is unequal and that it is therefore acceptable for courts to enjoin the operation of segregated schools, there are still many ways to define educational inequality, to determine whether it exists, and to attempt to eliminate it. ${ }^{228}$ Once, therefore, one moves beyond the core decision in Brown v. Board of Education, ${ }^{229}$ acceptance declines; unease about the courts' choices increases as confidence in the courts' ability to define, detect, and remedy inequality decreases. If one views the prison case as easier on the merits, it is because one can more easily define and measure the harm, and consequently accept even wide-ranging judicial activity to correct the constitutional violation. The reading case too would be simple if we were all sure there was only one decent way to teach children to read.

People perceive remedies as arbitrary and alternatives to them as acceptable when they do not really believe that the wrong to which the remedy is addressed constitutes a serious evil. The longer the line of development of a given area of substantive law, the more likely it is to have departed from the kind of immediately apprehensible evil that led courts to recognize a newly protected entitlement in the first place. School cases have been around for a long time, and the underlying substantive rights in litigation are no longer of the "shock the conscience" sort. ${ }^{230}$ Instead, with the refinement and development of the law since Brown, we may in some school cases have reached the point where not much more than some fancy jockeying for marginal advantage is at stake. $^{231}$ In time, if hospital and prison law lives and flourishes, we may encounter problems similar to those now encountered in educational equality cases. ${ }^{232}$ As the law moves

228 See, e.g., B. BRUdNo, Poverty, INEQUality aNd The LAW 279-80, 299-310, 318-22, 352-53, 386-93 (1976); Levin \& Moise, School Desegregation Litigation in the Seventies and the Use of Social Science Evidence: An Annotated Guide, 39 LAW \& CONTEMP. PROB. 50, 52-53 (1975); Schoettle, supra note 215, at 1393-95.

229347 U.S. 483 (1954).

${ }^{230}$ One combination of circumstances that renders school desegregation cases so messy is the frequent concurrence of litigan' intransigence (school boards have not been quick to desegregate even when they could) and doubt about how to measure and eliminate inequality.

231 See, e.g., A. Bickel, The Supreme Court and the IDEA of Progress I27-8I (1970); N. GlaZER, AfFirmative Discrimination 94-129 (1975).

232 Some think we may already have done so. Professor Mishkin is one of the few critics of institutional litigation willing to suggest that the courts may be wrong on the merits. Mishkin, supra note 2, at 955, $97 \mathrm{I}-72$. But cf. id. at 950 (not questioning legitimacy of detailed institutional decrees "where the constitutional right is clearly and soundly based and there is no alternative way to effectuate it"). 
from core cases to their entailments, the technicality of the distinctions becomes more apparent, and the need for any intervention less so. In the end, one cannot avoid the merits.

\section{CONCLUSION}

That the merits do finally matter is one of the two central points we have tried to make. The second point can be stated just as simply: those who have seen institutional litigation not just as new cases but as a fundamentally different kind of work for the courts exaggerate the degree of change. They overstate the extent of purely doctrinal change. Less has happened, either on the exalted planes of federalism and constitutional remedy or on the homelier ones of common law adjudication and litigative practice, than one would gather from reading the commentators. Nor does this picture change dramatically if one looks at the new litigation functionally; courts have for some time reordered the affairs of complex institutions.

We do not deny that courts have been up to new things, but we conclude that the novelty flows from the new rights created rather than from the remedies employed. Twenty-five years ago few thought the Constitution guaranteed mental patients clean sheets or prisoners hearings before parole revocation. Having found such rights implied by the Constitution, courts have reached for a remedial arsenal fitted out centuries ago for service in other wars. The weapons are not new, but the cause is, and one must finally evaluate such litigation in terms of its ends rather than its means.

Failure to place institutional litigation in perspective as part of a more complex legal and political tradition does not merely lead to exaggeration of the discontinuity between past and present legal custom. Such an asserted discontinuity also has a life of its own. It rewrites our collective political and institutional history, creating a mythical past in which courts and legislatures were very different entities walking on clearly demarcated and entirely separate paths. This mythical past suggests the illegitimacy of an action by a court that moves over the invisible line between adjudication and legislation. Under this view, a court that orders a hospital to maintain sanitary conditions must be beyond the boundaries of its institutional competency. Furthermore, by insisting on the outrageousness of such institutional trespasses, the myth shifts attention from the merits of allocating funds to provide minimally decent hospital or prison conditions to the question 
whether courts should administer prisons. That should not be the question.

But there should be some question - some real question - as to ends rather than means. As to those ends we claim no special wisdom. On the whole, we favor many of the actions of courts in institutional litigation on the grounds that they tend to foster rather minimal standards of human dignity, but we do not think that such a preference is susceptible of proof. We would insist, however, that it is such questions, rather than those of technique and administration, that the new litigation requires us to confront. 